\title{
HOUSING FOR YOUTH AgING OUT OF FOSTER CARE
}

\section{A REVIEW OF THE LITERATURE AND PROGRAM TYPOLOGY}
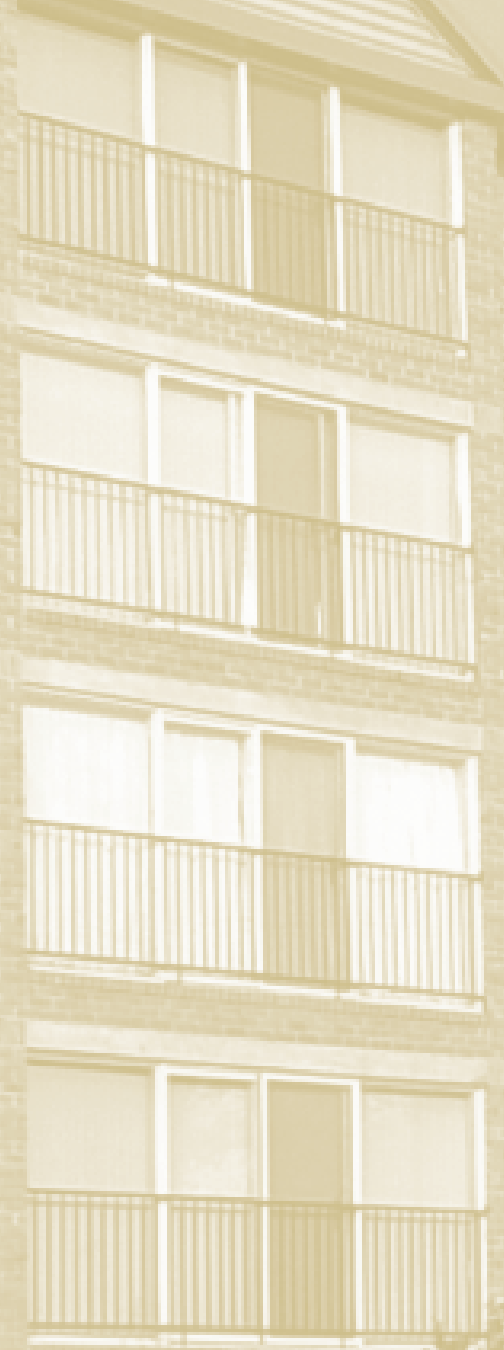
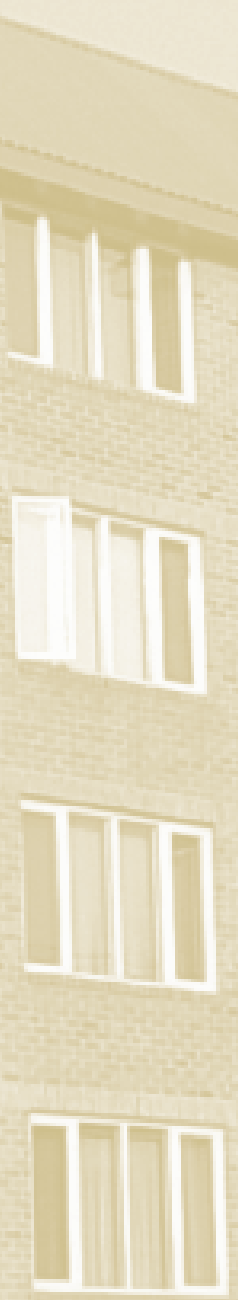

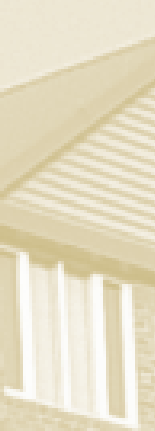

1111

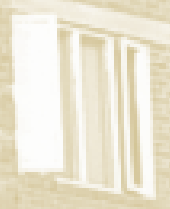

II
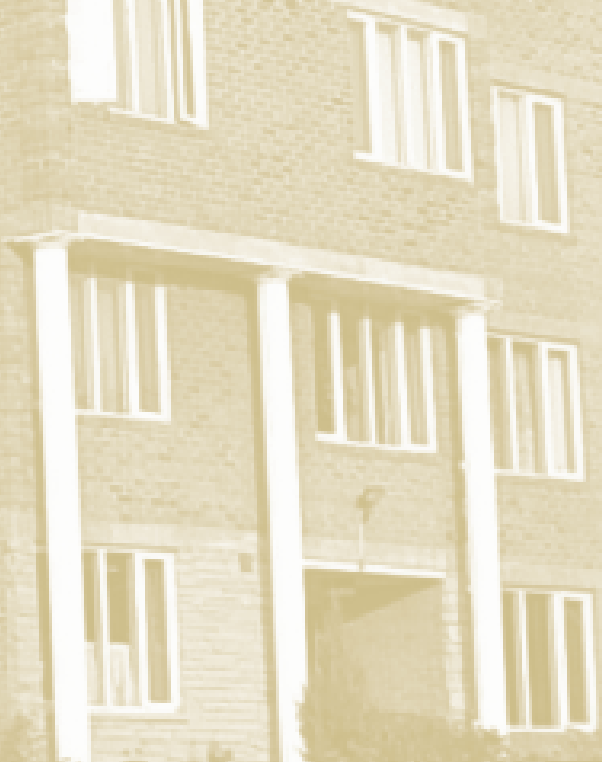


\section{HOUSING For YOUTH Aging OUt OF Foster CARE}

A ReView of the Literature and Program Typology

PREPARED FOR:

U.S. Department of Housing and Urban Development

Office of Policy Development \& Research

PREPARED BY:

Amy Dworsky

Keri-Nicole Dillman

M. Robin Dion

Brandon Coffee-Borden

Miriam Rosenau

Mathematica Policy Research

Washington, DC

CONTRACT NUMBER:

C-CHI-01120 CHI-T0001

April 2012 


\section{CONTENTS}

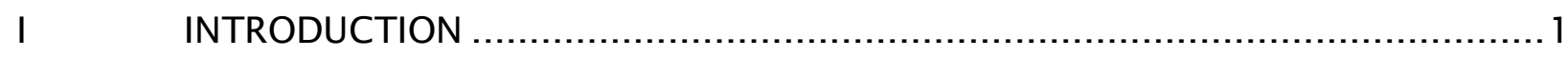

II THE HOUSING NEEDS OF YOUNG PEOPLE AGING OUT OF FOSTER

CARE

A. What Are the Characteristics of the Population? .................................... 3

B. What Do We Know About the Housing Outcomes of Young People Who Have Aged Out of Foster Care?............................................ 4

1. Prevalence of Homelessness and Housing Instability ....................... 4

2. Predictors of Homelessness ..................................................... 7

C. Why Does Housing Matter During the Transition to Adulthood? ...............8

D. What Barriers to Stable Housing Do Youth Aging Out of Care

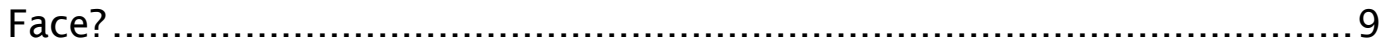

1. Individual Characteristics of Youth Aging Out of Foster Care ............. 9

2. Child Welfare System Factors....................................................... 11

3. Housing Markets............................................ 13

E. What Policies and Programs Address the Housing Needs of Young People Aging Out of Foster Care?............................................. 14

1. Chafee Foster Care Independence Program ..................................14

2. Education and Training Voucher Program .................................... 15

3. Fostering Connections to Success and Increasing Adoptions

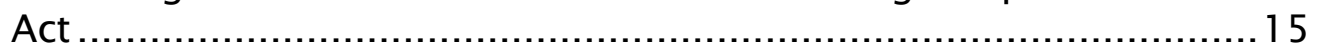

4. Family Unification Program (FUP) .............................................. 16

5. Public Housing and Section 8 Housing Choice Voucher

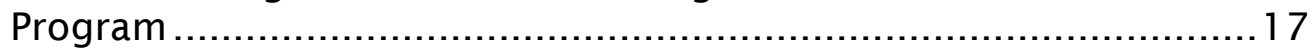

6. Transitional Living Program..................................................... 17

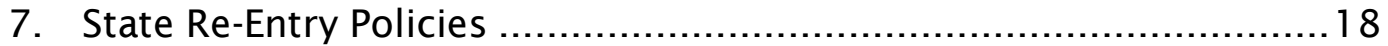

III. STATE AND LOCAL HOUSING PROGRAMS FOR YOUNG PEOPLE AGING

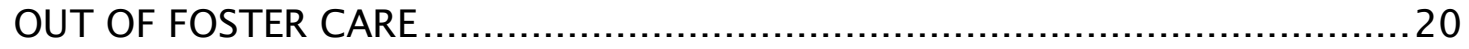

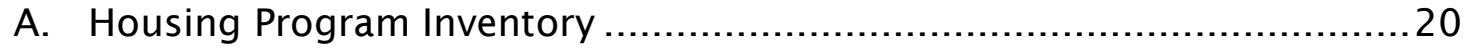

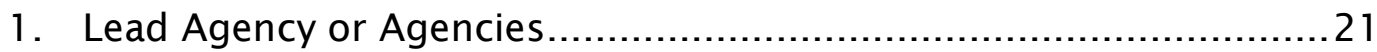

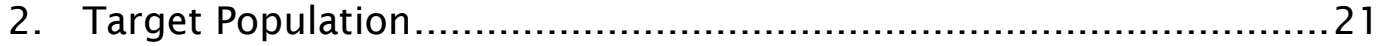

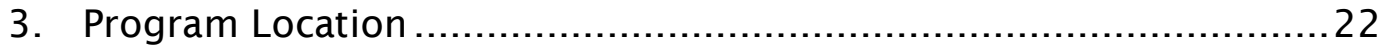

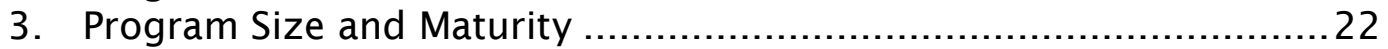

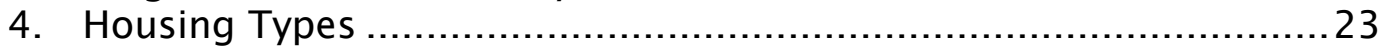

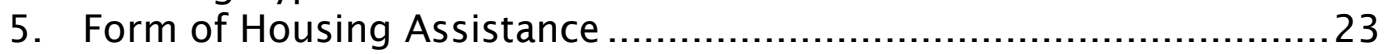

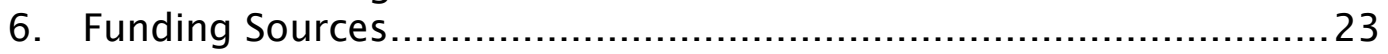

7. Youth Contribution to Rent or Savings.......................................24 
III (continued

8. Delivery of Supportive Services ........................................... 24

9. Aftercare services .............................................................. 25

10. Community building and relationship development ....................25

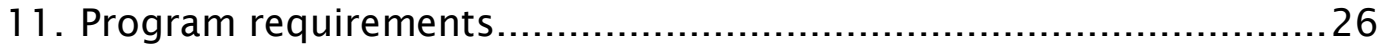

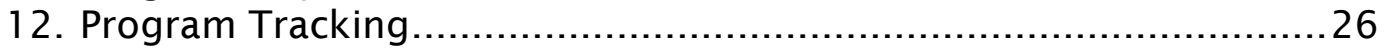

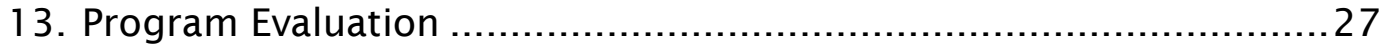

14. Challenges associated with rigorous evaluation .......................... 28

B. A Typology of Youth Housing Programs....................................29

1. Single-Site Programs with Supervision and Supportive Services............................................................................29

2. Scattered-Site Programs with Less Supervision and Supports ...........30

3. Programs with Multiple Housing Types and Varying Levels of Supervision and Support .............................................. 31

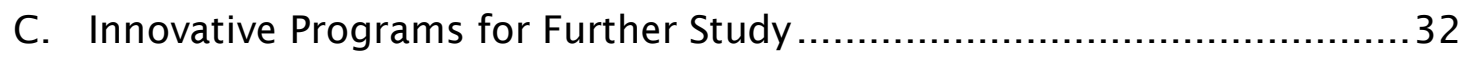

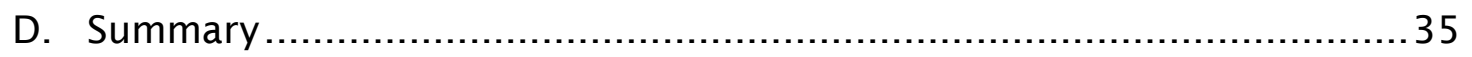

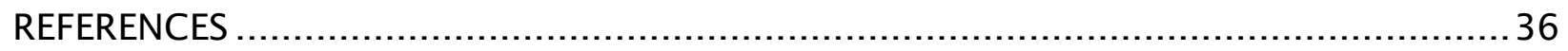

APPENDIX A: INVENTORY OF SELECTED HOUSING PROGRAMS FOR YOUTH

AGING OUT OF FOSTER CARE........................................... 46 


\section{TABLES}

II.1 Homelessness and Housing Instability Among Former Foster Youth...............5

III.1 Innovative Housing Programs for Former Foster Youth................................32 


\section{INTRODUCTION}

Most young people in the United States are experiencing an increasingly prolonged transition to adulthood. It is no longer assumed that they will automatically become self-sufficient adults on their 18th or even 21st birthdays (Arnett 2000; Wight, Xhau, Aratani, Schwarz, and Thampi 2010; Setterstein and Ray 2010). Rather, young people are gradually taking on the roles and responsibilities traditionally associated with adulthood while they acquire the education and work experience needed to become economically independent (Berlin, Furstenberg, and Waters 2010). This is often made possible by direct financial assistance and other support provided by parents or other family members (Furstenberg, Rumbaut, and Settersten 2005; Arnett 2000; Settersten, Furstenberg, and Rumbaut 2005; Shanahan 2000; Yelowitz 2007). In fact, it is now normative for young people to remain at least somewhat economically dependent on their families well past age 18.

The transition for young people who exit foster care not through reunification, adoption, or legal guardianship, but rather by aging out, is much more abrupt (Osgood, Foster, Courtney 2010). At age 18 or, in some states, at age 21, these young adults are expected to shift from being dependents of the state to being independent young adults virtually overnight. As part of the accelerated transition (Wade and Dixon 2006), young people aging out of foster care must find and maintain suitable housing-in most cases, with little or no support from either their family or the state (Brown and Wilderson 2010).

In this document, we summarize what is known about the housing needs and outcomes common to young people who age out of foster care. We explore the current landscape of programs and resources available to assist such young adults with housing. In the first section, we review the literature on the characteristics of the young people, their risk of homelessness, and the barriers they face in securing stable housing, along with relevant federal and, to a lesser extent, state policies. In the second section, we describe a wide range of housing programs for young people aging out of

foster care, present a program typology, and conclude with the identification of a small group of innovative housing programs that may warrant closer exploration. 



\section{THE HOUSING NEEDS OF YOUNG PEOPLE AGING OUT OF FOSTER CARE}

Over the last few decades, researchers have learned a great deal about the experiences of youth aging out of foster care. The literature suggests that these young people experience high rates of homelessness and housing instability while pointing to several barriers that contribute to such outcomes. Less is known about the effectiveness of federal and state policies and programs aimed at addressing their housing needs.

\section{A. What Are the Characteristics of the Population?}

The Adoption Assistance and Child Welfare Act of 1980 (PL 96-272) dictated permanency as the goal for all children and youth placed in foster care. A large share of the children and youth who enter foster care achieve permanency either by returning to their families, or increasingly, through adoption and legal guardianship (Wulczyn, Hislop, and Chen 2005). However, for a significant number of youth in an out-of-home care placement, permanency remains an elusive goal. While some of these young people are transferred to a psychiatric hospital or correctional facility and others exit by running away (Courtney and Barth 1996), most remain in foster care until they "age out" at age 18 or, in a growing number of states, at age 21 .

After increasing steadily for more than a decade, the number of young people aging out of foster care each year peaked at approximately 29,500 in federal fiscal year (FFY) 2009 before falling to just under 28,000 in FFY 2010 (U.S. Department of Health and Human Services 2011). Like the total U.S. child welfare population, these young people are disproportionately youth of color, and the families from which they were removed are predominantly low-income (General Accountability Office 2007). Most entered foster care following a determination that they had been neglected or abused, although possible reasons for placement also include parental incapacitation, child behavior problems, and, in some states, juvenile delinquency.

However, recent research suggests that young people aging out of care are a heterogeneous group with distinct subpopulations (Keller, Cusick, and Courtney 2007; Vaughn, Shook, and McMillen 2008). Although some will have spent much of their childhood in foster care, many will have been adolescents when they first entered (Courtney and Barth 1996; Fowler et al. 2009; Needell, Cuccaro-Alamin, Brookhart, Jackman, and Shlonsky 2002; Wulczyn, Hislop, and Goerge 2001; Wulczyn 2009). Their experiences in "the system" could range from a single stable placement with a relative or foster family to several placements in group homes and residential care facilities. The nature and quality of services, including services to prepare young people for the transition to adulthood, may also vary greatly, depending on the state and even county responsible for their care.

Despite such heterogeneity, research over the past three decades suggests that many young people aging out of foster care are not prepared for the transition to adulthood. As a group, they fare more poorly than their peers across a variety of domains, including education and employment (e.g., Barth 1990; Cook et al. 1991; Collins 2001; Courtney and Dworsky 2006; Courtney, Piliavin, Grogan-Kaylor, and Nesmith 2001; Courtney, Dworsky, Cusick, Havlicek, Perez, and Keller 2007; Courtney, Dworsky, Lee, and Raap 2010; Courtney, Dworsky, Brown, Cary, Love, and Vorhies 2011; Dworsky 2005; George et al. 2002; Macomber et al. 2008; Buehler et al. 2000). Foster youth are more likely to experience adverse outcomes such as early parenthood, criminal justice system involvement, economic hardships, and public assistance receipt (Barth 1990; Cook et al. 1991; Courtney et al. 2001). 


\section{B. What Do We Know About Housing Outcomes of Young People Who Have Aged Out of Foster Care?}

\section{Prevalence of Homelessness and Housing Instability}

One of the domains of particular interest to researchers is homelessness and housing instability. Currently, there are no national estimates of homelessness during the transition to adulthood among young people who age out of foster care. However, this situation will begin to change over the next few years now that states must ask foster youth if they have been homeless as part of the National Youth in Transition Database (NYTD) outcome survey. ${ }^{1}$ A baseline outcome survey is administered at age 17; a follow-up outcome survey is administered at ages 19 and $21{ }^{2}$

The first wave of NYTD data was collected in FY 2011, but almost all of the 17 year olds who completed the baseline survey were still in foster care. Therefore, those data cannot be used to estimate the rate of homelessness among transitioning foster youth. ${ }^{3}$ A national estimate will not be available until after the follow-up survey data are collected in FY 2013 and FY 2015².

What we do know about the prevalence of homelessness during the transition to adulthood comes from research published over the past two decades (Table II.1). These studies have consistently found a relatively high rate of homelessness among young people who aged out of foster care (Barth 1990; Cook, Fleishman, and Grimes 1991; Brandford and English 2004; Reilly 2003; Fowler, Toro, Tompsett, and Hobden 2006; Dworsky and Courtney 2009; Dworsky and Courtney 2010; Courtney, Dworsky, Brown, Cary, Love, and Voorhies 2011; Courtney, Piliavin, Grogan-Kaylor, and Nesmith 2001; Fowler, Toro, and Miles 2009; White et al. 2011). However, estimates vary widely, ranging from a low of 11 percent (Brandford and English 2004) to a high of 36 percent (Reilly 2003). The variation reflects differences across studies in the age at which the former foster youth were interviewed, the geographic region where the youth had been in care, the length of time since exit, the representativeness of the sample, and the definition of homelessness.

The same body of research suggests that homelessness is but one manifestation of housing instability among young people who age out of foster care. Another manifestation is temporary residence with others. More specifically, several of the studies cited above also find high rates of couch surfing or doubling up because young people could not afford housing on their own (Cook et al. 1991; Brandford and English 2004; Fowler, Toro, Tompsett, and Hobden 2006; Dworsky and Courtney 2009; Dworsky and Courtney 2010; Courtney, Dworsky, Brown, Cary, Love, and Voorhies

\footnotetext{
${ }^{1}$ States are required to use the 22 survey questions listed in Appendix B of the Final Rule (45 CFR, Part 1356) that was issued by the Administration for Children and Families on February 26, 2008. However, they have discretion with respect to how and by whom the survey is administered.

2 One baseline survey question (Have you ever been homeless?) and one follow-up survey question (In the past two years, were you homeless at any time?) ask about homelessness.

3 All 50 states plus the District of Columbia and Puerto Rico collected and reported NYTD outcome survey data for the most recent reporting period (April 2, 2011 - September 30, 2010).

4 The NYTD data collection plan was designed before the Fostering Connections to Success and Increasing Adoptions Act of 2008 extended eligibility for federal Title IV-E reimbursement to age 21. As the number of states that take advantage of this law increases, an increasing percentage of foster youth will be able to remain in care until their 21st birthday. Consequently, the NYTD survey data, which must be collected within 45 days after youth turn age 21, will be less useful for estimating the rate of homelessness among this population.
} 
2011; Fowler, Toro, Tompsett, and Hobden 2006). Again, estimates vary ranging from one-quarter to one-half.

In addition, and perhaps more commonly, young people who have aged out of care experience periods in which they are precariously housed. They may live with others, but the arrangement is not permanent. On the other hand, they may occasionally live on their own but are unable to maintain their housing. The precariousness of their housing is most clearly indicated by their high rate of residential mobility. Several studies have found that former foster youth frequently report several moves soon after leaving care (Dworsky and Courtney 2009; Courtney et al. 2010; Reilly 2003) and tend to experience more mobility than their peers in the general population (Courtney et al. 2005; 2007; 2010). Although some degree of mobility is probably normative for this age group (Collins 2011, some moves may occur for desirable reasons - the ability to afford a larger apartment or an apartment in a safe neighborhood or relocating for a new job or to attend school. However, several moves within a short time are generally not beneficial (Burgard, Seefeldt, and Zelner 2012; Shinn and Weitzman 1996).

Table II.1. Key Studies of Homelessness and Housing Instability Among Former Foster Youth

\begin{tabular}{|c|c|c|}
\hline Study & Sample & Housing Outcomes \\
\hline \multirow[t]{3}{*}{ Barth (1990) } & $\begin{array}{l}\text { Convenience sample of } 55 \text { young people in San } \\
\text { Francisco Bay/ Sacramento area }\end{array}$ & \multirow[t]{3}{*}{$\begin{array}{l}29 \% \text { had been homeless or had } \\
\text { moved at least once a week }\end{array}$} \\
\hline & Mean age of 21 years old & \\
\hline & $\begin{array}{l}\text { Had exited foster care between } 1 \text { and } 10 \text { years } \\
\text { before when they were } 16 \text { to } 19.5 \text { years old }\end{array}$ & \\
\hline \multirow[t]{3}{*}{$\begin{array}{l}\text { Brandford and English } \\
(2004)\end{array}$} & $\begin{array}{l}213 \text { young people from Washington State who } \\
\text { had been in foster care for at least a year }\end{array}$ & \multirow{2}{*}{$\begin{array}{l}11 \% \text { had been homeless (i.e., } \\
\text { slept in a shelter, in a car, or on } \\
\text { the street) }\end{array}$} \\
\hline & $70 \%$ of baseline sample of 302 & \\
\hline & $\begin{array}{l}\text { Follow-up interview } 6 \text { to } 12 \text { months post- } \\
\text { emancipation }\end{array}$ & $25 \%$ had "couch surfed" \\
\hline \multirow[t]{4}{*}{$\begin{array}{l}\text { Cook, Fleishman, and } \\
\text { Grimes (1991) }\end{array}$} & $\begin{array}{l}810 \text { young people who aged out of foster care } \\
\text { in } 7 \text { states (AZ, CA, IL, MS, PA, NY, TN) and } \\
\text { Washington, D.C. between } 1 / 87 \text { and } 6 / 88\end{array}$ & \multirow{4}{*}{$\begin{array}{l}25 \% \text { had been homeless (i.e., at } \\
\text { least one night in a shelter, on the } \\
\text { streets, or in a car or had no place } \\
\text { to live so stayed with friends) }\end{array}$} \\
\hline & $49 \%$ of baseline sample of 1,644 & \\
\hline & 18 to 28 years old & \\
\hline & Out of care for 2.5 to 4 years & \\
\hline \multirow[t]{3}{*}{$\begin{array}{l}\text { Collins, Spencer, and } \\
\text { Ward }(2010)\end{array}$} & $\begin{array}{l}96 \text { young people from Massachusetts who } \\
\text { turned } 18 \text { in } 2005 \text { and were at least } 18 \text { years } \\
\text { old when the exited foster care }\end{array}$ & \multirow[t]{3}{*}{$\begin{array}{l}37 \% \text { had ever been homeless } \\
\text { since age } 18\end{array}$} \\
\hline & Age 19 and older at time of data collection & \\
\hline & $15 \%$ of the eligible population of 660 & \\
\hline \multirow{3}{*}{$\begin{array}{l}\text { Courtney, Piliavin, } \\
\text { Grogan-Kaylor and } \\
\text { Nesmith (2001) }\end{array}$} & 113 young people from Wisconsin & \multirow{3}{*}{$\begin{array}{l}12 \% \text { had been homeless at least } \\
\text { once (i.e., at least one night on } \\
\text { the streets or in a shelter) } \\
22 \% \text { had lived in four or more } \\
\text { places }\end{array}$} \\
\hline & $80 \%$ of baseline sample of 141 & \\
\hline & $\begin{array}{l}\text { Follow up interview } 12 \text { to } 18 \text { months months } \\
\text { post-discharge }\end{array}$ & \\
\hline
\end{tabular}




Study
Daining and DePanfilis
(2007)
Fowler, Toro, and Miles
(2009)

(2009)

Sample

100 young people who exited foster care in Maryland between 10/99 and 9/00 when they were 18 to 21 years old $53 \%$ of the eligible population of 189 Ages 19 to 24 at time of interview Time since exit ranged between 20 and 37 months, with a mean of 27

265 young people who aged out of care in the metropolitan Detroit-area in 2002 and 2003

Average of 3.6 years since exit $34 \%$ of the eligible population of 867
Fowler, Toro, Tompsett and Hobden (2006)
264 young people who aged out of care in the metropolitan Detroit-area in 2002 and 2003

Average of 3.6 years since exit

$34 \%$ of the eligible population of 867

$58 \%$ had continuously stable housing

$12 \%$ experienced increasingly stable housing $11 \%$ experienced decreasingly stable housing, including literal homelessness $20 \%$ had continuously unstable housing (i.e., moving between being literally homelessness and precariously housed)

$17 \%$ had been homeless at least once (i.e., at least one night on the streets, in an abandoned building, in a car, or in a shelter $33 \%$ had "doubled up" or couch surfed

Average of 4.3 living arrangements since leaving foster care

Dworsky and Courtney (2009)
Sample of 732 young people from IA, WI and IL who entered care prior to age 16 and were still in care on 17 th birthday

321 study participants who had exited foster care by age 19

\section{Dworsky and Courtney (2010) \\ Courtney, Dworsky, Lee, and Rapp (2010) \\ Courtney, Dworsky, Brown, Cary, Love and Vorhies (2011)}

Pecora, Kessler, Williams, O'Brien, Downs, English, White, Hiripi, White, Wiggins and Holmes (2005)*
Sample of 732 young people from IA, WI and IL who entered care prior to age 16 and were still in care on $17^{\text {th }}$ birthday

602 study participants interviewed at age 23 or 24

Sample of 732 young people from IA, WI and IL who entered care prior to age 16 and were still in care on $17^{\text {th }}$ birthday

591 study participants interviewed at age 26

\section{9 foster care alumni from Oregon and} Washington State

20 to 33 years old

At least 12 months in foster care between 14 and 18 years old $73 \%$ of baseline sample of 659

Received foster care services from Casey Family Services and/or from the public child welfare
$14 \%$ had been homeless for at least one night

$60 \%$ of 1 st homeless spells began within six months of exiting

$26 \%$ of the never homeless had moved at least three times

$30 \%$ had been homeless for at least one night

$37 \%$ had been homeless or "couch surfed"

$48 \%$ had lived in four or more places post-exit

$31 \%$ had been homeless (15\%) or couch-surfed (25\%) since their last interview ( 30 months)

$22 \%$ had been homeless for at least one night within a year of exit 


\begin{tabular}{|c|c|c|}
\hline Study & Sample & Housing Outcomes \\
\hline \multirow{5}{*}{$\begin{array}{l}\text { Pecora, Williams, } \\
\text { Kessler, Downs, } \\
\text { O’Brien, Hiripi and } \\
\text { Morello (2003)* }\end{array}$} & $\begin{array}{l}1,087 \text { Casey Family Services foster care alumni } \\
\text { from } 13 \text { states }\end{array}$ & \multirow[t]{5}{*}{$\begin{array}{l}22 \% \text { were homeless for at least } \\
\text { one night within a year of exit }\end{array}$} \\
\hline & $\begin{array}{l}\text { Received services for at least } 12 \text { months } \\
\text { between } 1966 \text { and } 1998\end{array}$ & \\
\hline & $68 \%$ of the 1,609 alumni population & \\
\hline & Had exited foster care at least one year before & \\
\hline & 20 to 51 years old, with mean age of 30.5 & \\
\hline \multirow[t]{3}{*}{ Reilly (2003) } & $\begin{array}{l}100 \text { young people who aged out of foster care } \\
\text { in Clark County (Las Vegas), Nevada at age } 18 .\end{array}$ & $\begin{array}{l}36 \% \text { had lived on the streets ( } 19 \%) \\
\text { or in a shelter (18\%) }\end{array}$ \\
\hline & \multirow[t]{2}{*}{$\begin{array}{l}\text { Data collected } 6 \text { months to } 3 \text { years post- } \\
\text { discharge }\end{array}$} & $\begin{array}{l}35 \% \text { had moved at least five } \\
\text { times. }\end{array}$ \\
\hline & & $\begin{array}{l}\text { Nearly one third were discharged } \\
\text { from care without a place to live }\end{array}$ \\
\hline \multirow{3}{*}{$\begin{array}{l}\text { Roller White, Gallegos, } \\
\text { O'Brien, Weisberg, } \\
\text { Pecora and Medina } \\
(2011)^{*}\end{array}$} & $\begin{array}{l}542 \text { foster care alumni (ages 19, 22, and } 25 \\
\text { years old) }\end{array}$ & $\begin{array}{l}20 \% \text { had been homeless since } \\
\text { leaving care }\end{array}$ \\
\hline & $48 \%$ of the 1135 eligible alumni & \multirow{2}{*}{$\begin{array}{l}\text { Median length of homeless spell } \\
\text { was } 90 \text { days }\end{array}$} \\
\hline & $\begin{array}{l}\text { Received services from Casey Family Services for } \\
\text { at least } 12 \text { months }\end{array}$ & \\
\hline
\end{tabular}

*Includes foster care alumni who did not age out.

Inability to pay rent consistently is another indicator of precarious or unstable housing. Research suggests that inconsistent rent payment is a common problem among former foster youth. Compared to their peers in the general population, young people who have aged out of foster care are more likely to report the inability to make a rent payment and are more likely to report an eviction (Courtney and Dworsky 2005; Courtney et al. 2007; Courtney et al. 2010; Courtney et al. 2011).

Despite evidence of poor housing outcomes among the former foster population, it is wrong to conclude that the young people in these studies became homeless or experienced housing instability as a consequence of foster care in and of itself. Young people aging out of foster care bring with them a host of other risk factors that could contribute to housing instability. Although at least one study found a higher rate of homelessness and housing instability among former foster youth than among a matched sample of "at risk" youth, the former foster youth sample was not limited to young people who had aged out of foster care but rather included those who achieved permanency through reunification, adoption, or legal guardianship (Berzin, Rhodes, and Curtis 2011).

\section{Predictors of Homelessness}

Despite considerable evidence that youth aging out of foster care are at high risk of homelessness, little is known about the predictors of homelessness among the former foster care population. Researchers have compared young people who experienced homelessness after leaving foster care to young people who aged out of foster care but did not become homeless (White et al. 2011; Fowler et al. 2009). Although the studies suggest that certain characteristics, such as mental health problems, may be more common among those who became homeless, the studies' crosssectional design makes it difficult to determine the direction of causality.

One study used longitudinal data to identify demographic, family background, or placement history characteristics that either contribute to or protect against homelessness during the transition 
to adulthood (Dworsky and Courtney 2010). Most notably, feeling close to at least one adult family member reduced the odds of homelessness by age 19 by more than half. Although the researchers could not examine why closeness to family matters, they speculated that young people can turn to family members to whom they feel close if, for example, they need help paying rent or a place to live. Behaviors exhibited while in foster care also predicted whether young people became homeless. Specifically, running away more than once and engaging in delinquency both increased the odds of homelessness.

Additional prospective studies are needed to identify not only risk but also protective factors. The results would allow resources to be directed to those most likely to become homeless without some type of intervention.

\section{Why Does Housing Matter During the Transition to Adulthood?}

The benefits of a safe and stable place to live are widely recognized. A growing body of literature suggests that, in addition to meeting the basic human need for shelter, safe and stable housing can function as a "platform" that promotes positive outcomes across a range of domains from education to employment to physical and mental health. Conversely, living in housing that is unsafe or unstable can be a significant impediment to positive outcomes (MacArthur Foundation 2012).

Housing stability matters throughout life but may be especially important during certain developmental stages such as the transition to adulthood because of its relationship to selfsufficiency. A lack of stable housing can impede efforts to become self-sufficient. It is difficult for young people to pursue education and training or to find and keep a job if their housing is unstable. Conversely, young people are better able to continue their schooling and maintain gainful employment if they are stably housed (Johnson et al. 2010; Sommer, Wu, and Mauldon 2009).

Stable housing is equally important to other aspects of well-being (Kushel et al. 2005; Phinney, Danziger, Pollack, and Seefeldt 2007; Reid, Vittinghoff, and Kushel 2008; Prevalin, 2009; Burgard, Seefeldt, and Zelner 2012). Stably housed young people find it much easier to access needed health care and social services; thus, housing stability contributes to good physical and mental health (Wade and Dixon 2006). Conversely, lack of stable housing can reduce access to health care and social services (Kushel et al. 2007) and hence contribute to or compound physical and mental health problems (Fowler, Toro, and Miles 2009). In fact, unstable housing can create a negative feedback loop. Unstable housing can compromise physical and mental health; poor physical and mental health can limit labor market participation, and limited employment can lead to housing instability (Collins, 2011).

Although young people aging out of foster care may experience unstable housing without becoming homeless, housing instability can be an antecedent to homelessness, which is of particular concern because of the link between homelessness and various negative outcomes. Researchers have found that homeless youth and young adults are at increased risk of physical and sexual victimization (Whitbeck, Hoyt, Yoder, Cauce, and Paradise 2001); mental health and substance use problems (Halley and English 2008; U.S. Department of Health and Human Services 2001), and poor physical health (Ammerman et al. 2004; Feldmann and Middleman 2003). The few studies that have looked at the well-being of young people who became homeless after aging out of foster care suggest that these young people are more likely to suffer from mental health problems (White et al. 2011; Fowler et al. 2009), experience physical and sexual victimization (Fowler et al. 2009), and lack access to health care (Kushel et al. 2007) than their peers who aged out of foster care but did not 
become homeless. The findings are consistent with the larger body of research on homeless youth and, in general, young adults (Toro, Dworsky, and Fowler 2008).

\section{What Barriers to Stable Housing Do Youth Aging Out of Care Face?}

For many young adults, finding safe and affordable housing and then maintaining that housing can pose a challenge (Mech 2003). However, for a variety of reasons, the challenges may be especially formidable for those aging out of foster care. Some individual-level characteristics make it difficult for former foster youth to earn an income sufficient to cover rent payments. In addition, the characteristics of the child welfare system leave former foster care youth ill-prepared for living independently, and local housing market characteristics typically limit housing options.

\section{Individual Characteristics of Youth Aging Out of Foster Care}

Inadequate Income and Assets. The ability to achieve self-sufficiency is directly tied to success in the labor market. Far too many young people age out of foster care without a high school diploma or a GED and then fail to complete high school thereafter (Burley 2009; Courtney, Piliavin, Grogan-Kaylor, and Nesmith 2001; Courtney et al. 2007; Courtney et al. 2012; Burley and Halpern 2001; Smithgall et al. 2004; Washington State Department of Social and Health Services 2001; Wolanin 2005). Compared with their peers in the general population, young people who are aging or who have aged out of foster care are also less likely to attend college and to graduate with a degree if they do attend college (Courtney, Dworsky, Lee, and Rapp 2010; Wolanin 2005; Burley 2009; Burley 2010; Davis 2006; Day et al. 2011). At a time when a post-secondary credential is increasingly essential for securing gainful employment, young people aging out of foster care are at a significant disadvantage in the labor market. This, in turn, limits their ability to find and maintain housing that is both affordable and safe.

Young people aging out of foster care are also at a disadvantage in the labor market because they lack preparation for employment. Although some foster youth receive workforce development services in the form of job readiness training and may have opportunities to gain work experience through subsidized job placements, others exit foster care without knowing how to write a resume, fill out a job application, or arrive at work on time. Moreover, workforce development programs that target foster youth have generally not been the subject of evaluations, although the few evaluations conducted to date suggest that workforce development programs do not produce promising results (Casey Family Programs Study of EMPLOY, Dworsky and Havlicek 2010).

Too often, the human capital deficits of former foster youth are compounded by a lack of social capital. Research suggests that access to social networks and resources can be important in efforts to seek employment (Lin 1999; Granovetter 1995). Young people aging out of care may not have had an opportunity to develop relationships with adults who can connect them with employers in a position to offer either entry-level jobs or internships. The lack of social capital may be particularly problematic for foster youth placed in group homes or other congregate care settings. Such settings are not conducive to the development of lasting relationships with supportive adults.

Deficits in human and social capital are not the only factors that may limit the ability of young people aging out of foster care to secure adequate income and hence pay for suitable housing. Former foster youth are more likely than their non-foster care counterparts to describe their health as fair or poor (Courtney et al. 2007) or to report a serious health problem (Reilly 2003). They exhibit higher rates of mental health and substance use disorders than young adults in the general population (Keller et al.2010; Pecora et al.2003; Vaughn, Ollie, McMillen, Scott, Munson, 2007). 
They are also more likely to have a criminal record (Courtney, Dworsky, Ruth, Havlicek, Perez, and Keller 2007).

Equally important, young people aging out of foster care face a labor market characterized by scarce entry-level jobs and high competition. The persistently high unemployment rate that has typified both the recent recession and the recovery has hit young adults especially hard (Sum, Khatiwada, and Palma 2010). Young people under age 25 are much more likely to be unemployed than their older counterparts (U.S. Department of Labor, Bureau of Labor Statistics 2011). Given their human and social capital deficits, young people aging out of foster care are at an even greater disadvantage than their peers.

Just as inadequate income makes it difficult for young people aging out of foster care to pay rent or utility bills, inadequate assets can be a problem. Young people frequently age out of foster care with few if any assets (Pecora et al. 2005), and former foster youth are less likely than their peers to have accumulated savings in a bank account (Courtney et al. 2005; Courtney et al., 2007). Accordingly, many will not be able to come up with the money for the first and last months' rent or a security deposit, both of which may be required to rent an apartment (Brooks-Gunn \& Duncan 1997; Corcoran and Chaudry 1997).

No Family Safety Net. Family can be an important resource for young people during the transition to adulthood. Parents often provide their adult children with substantial financial support, including assistance with rent payments. Young people aging out of foster care cannot count on family for such assistance.

Parents can also offer in-kind assistance with housing by providing a place to live (Schoeni and Ross 2004). A growing number of young adults live with one or both parents (Fields 2003; Brown, Moore, and Bzostek 2003; Yelowitz 2007). In 2009, 53 percent of children age 18 to 24 were living at home compared with 47 percent in 1970 (Wright et al. 2010). Although some of these young people never left home, others moved out, only to return (Rumbaut 2006; Goldscheider and Goldscheider 1994). Not surprisingly, "reverse transitions" often occur in the wake of a financial setbacks, such as job loss (Swartz, Kim, Uno, Mortimer, and O’Brien 2011).

It would be wrong to assume that residing with parents is never an option for young people aging out of foster care. On the contrary, several studies suggest that it is not uncommon for young people to move into the home of a parent after aging out (Fowler et al. 2006; Cook et al. 1991; Courtney et al. 2001; Courtney et al. 2005; 2007; 2009; Reilly 2003; Collins et al. 2010; Collins, Paris, and Ward 2008). However, they are much less likely to do so than their peers in the general population (Courtney et al. 2005; 2007; 2010; 2011).

It is unclear how researchers should interpret these returns home. On the one hand, the returns could be evidence that youth maintained family ties while in foster care. On the other hand, returns could indicate a lack of options. After all, in many cases, youth are returning to the same parent(s) who neglected or abused them and from whom they were removed. Another unknown is the duration of these living arrangements or their impact on other outcomes. Returning home could either promote or undermine youth efforts to achieve self-sufficiency, depending on whether a return home provides access to the same benefits, such as financial or emotional support, that other young people enjoy when living at home.

Although some foster youth may remain with their foster family after exiting the child welfare system, very few do so (Courtney et al. 2005; Courtney et al. 2007). One reason is that many young 
people no longer live in foster homes by the time they age out. Rather, they live in congregate care or independent living programs. It is also possible that another child needs their bed or that their foster parents cannot afford to provide room and board without maintenance payments from the child welfare agency. It is reasonable to expect that young people would be more likely to remain in their foster home after aging out if their foster parents are relatives, but such a hypothesis has yet to be examined.

Lack of Relationships with Supportive Adults. Living in foster care makes it difficult for young people to develop lasting relationships with adults who will continue to provide support during the transition to adulthood (Hyde and Kammerer 2009; Hines, Merdinger, and Wyatt 2005; Courtney and Hughes-Heuring 2005; D'Andrade 2005; Fanshel 1992). These relationships can be an important resource for young people faced with the challenge of finding suitable housing. Without these relationships, young people-particularly former foster youth who experienced several placements or resided in congregate care-must navigate the housing search process, negotiate relationships with landlords, or choose roommates all on their own.

Early Parenthood. The rate of teenage pregnancy is much higher among youth in foster care than among other adolescents (Dworsky and Courtney 2010; Gotbaum 2005; Pecora et al.; 2003). Consequently, many young people are already parents by the time they age out of foster care. Others become parents soon thereafter (Courtney et al. 2007; Courtney et al. 2010; Courtney et al. 2011; Singer 2006). Although young people aging out of foster care are much more likely to experience early parenthood than their peers who were not in foster care regardless of gender, young women are far more likely to be a custodial parent. Hence, young mothers formerly in foster care are disproportionately more likely to feel the impacts of early parenthood on their ability to find and maintain housing as they age out of foster care.

Nonetheless, it is not entirely clear whether being a young parent has a net positive or negative effect on the search for stable housing. On the one hand, it is easy to imagine how early parenthood might complicate what is already a major challenge. Many young parents have not completed high school and have minimal job skills. The demands of caring for a child can further limit prospects for self-sufficiency by making it more difficult to work or pursue education, let alone search for suitable housing. In addition, money spent on child needs cannot be used to pay for rent. On the other hand, early parenthood may make young people aging out of foster care eligible for Temporary Assistance for Needy Families (TANF) benefits or housing assistance not available to their nonparent peers.

Juvenile or Criminal Record. Research has shown that young people aging out of foster care are more likely to have been involved with the juvenile or criminal justice system than their peers in the general population and that involvement with the justice system is especially common among young men (Courtney et al. 2004; Courtney et al. 2005; Courtney et al. 2007; Cusick and Courtney, 2007). A criminal record may be more than just a barrier to employment because young people with a criminal record may find themselves ineligible for public housing or other housing assistance, and landlords may be reluctant to rent to them (Samuels and Mukamal 2004).

\section{Child Welfare System Factors}

Preparation for Independent Living. Youth in foster care are often not exposed to the types of informal life skills learning experiences that families typically provide. Similarly, youth in foster care often have little opportunity to practice basic daily living tasks (such as cooking, budgeting, or shopping) and develop the confidence that results from successful performance. The limited 
exposure to independent living may be especially the case for foster youth who experience several placement changes or are placed in congregate care, as frequently happens with older youth (Courtney et al. 2004; Needell et al. 2002; McMillen and Tucker 1999). Consequently, it is incumbent upon the child welfare system to provide services that prepare youth for the transition to adulthood.

Since the mid-1980s and the creation of the Title IV-E Independent Living Program, the federal government has been allocating funds to states to help prepare youth in foster care for the transition to adulthood (DeWoody, Ceja, and Sylvester 1993). Today, the primary source of those federal funds is the Chafee Foster Care Independence Program (the Chafee Program). Despite the federal investment, neither states nor the federal government routinely collected data on the provision of independent living services (U.S. Government Accountability Office 2004) until implementation of the National Youth in Transition Database (NYTD) in FY 2011. The absence of data is an important issue because Chafee-funded services are not an entitlement. Eligible youth who want services may not receive them, and youth who receive services may not receive what they need.

State child welfare administrators reporting on the types of services provided by their state and the recipients of those services reveal a persistent gap between the number of youth eligible for and presumably in need of independent living services and the number receiving them (GAO 1998; GAO 2004; GAO 2007). Studies that surveyed current or former foster youth about their preparation for independent living have drawn similar conclusions. That is, young people report receiving few of the types of services that Chafee dollars are intended to fund (Courtney, Lee, and Perez 2011; Cook et al. 1991; Courtney et al. 2001). Given what we know about the generally poor outcomes of the foster care population, it seems unlikely that young people did not receive help simply because they did not need it.

A key service many young people report not receiving is assistance finding and maintaining housing after they leave care (Courtney et al. 2004; Courtney et al. 2005; Courtney et al. 2007; Courtney, Piliavin, Grogan-Kalyor, and Nesmith 2001; Reilly 2003). As a result, young people may age out of foster care without knowing how to find a place to live, where they may apply for housing assistance, or what their rights and responsibilities as tenants are.

Youth may fail to receive the services they need to prepare them for the transition to adulthood for a variety of reasons. For example, it is difficult to engage some youth in services. However, at least part of the gap in service provision is attributable to the inadequacy of federal funds. Authorization for the Chafee Program has remained at $\$ 140$ million per year for more than a decade, despite a significant increase in the number of young people aging out of foster care, efforts to provide services at younger ages, and the expansion of eligibility to youth exiting care through adoption or legal guardianship after their 16th birthday. To exacerbate matters, each state's allocation of Chafee funds is proportional to the size of its foster care population, while the percentage of that population eligible for services differs across states. The result is gross inequities in dollars per eligible youth and, given that emancipation accounts for a different percentage of foster care exits in different states, in the percentage of eligible youth who receive services (GAO 2004; 2007).

Equally disconcerting is that the services received by young people may not help them make a successful transition to adulthood (Montgomery, Donkoh, and Underhill 2006; GAO 1999), particularly if services are limited to the type of classroom-based life skills training that is a mainstay of many independent living programs. Most of the studies examining the relationship between foster youth outcomes and receipt of independent living services are methodologically flawed. Studies 
using methodologically rigorous designs have produced, at best, mixed findings (Courtney, Zinn, Koralek, Bess, Stagner, Pergamitt and Johnson 2011).

Assistance Transitioning to Independent Living. In addition to not receiving adequate preparation for independent living while in foster care, young people cannot count on child welfare agencies for transitional assistance after they age out. Although nearly every state offers some aftercare services (Dworsky and Havlicek 2009) and states may fund such services with their Chafee dollars, availability is often limited. In some jurisdictions, youth receive little more than referrals to community-based agencies or other resources.

Among the most important aftercare services provided by states is assistance with housing, which may include transitional housing, housing subsidies, monthly stipends, or one-time payments for housing-related costs. However, both the adequacy and availability of housing assistance varies greatly, not only by state but also by the county where a youth lives. Housing subsidies may be insufficient in costly urban areas, some benefits may be available only to certain youth (e.g., full-time students), and programs may screen out those most in need of assistance.

States may spend up to 30 percent of their Chafee funds on "room and board" to help young people aging out of foster care address their housing needs. A survey of 44 states and the District of Columbia conducted by Chapin Hall at the University of Chicago found that most states were using their Chafee dollars to provide transitional housing or to pay for rent, security deposits, and utilities as well as for furniture and even food (Dworsky and Havlicek 2009). A majority of states also reported that they supplement the federal funds they spend on housing with state dollars.

Nevertheless, a large gap persists between the number of young people aging out who need transitional housing or other housing assistance and the number who receive it (GAO 2007). Part of the problem is that even if states spent every dollar that they could on housing former foster youth, they still would not meet the housing needs of some youth. Moreover, every Chafee dollar that states spend on "room and board" does not pay for other services.

Cross-System Coordination. Yet another barrier to stable housing among young people aging out of foster care is a lack of systems integration. Many jurisdictions do not coordinate services between the child welfare system and other public systems, such as public schools, departments of workforce development, and, of particular relevance to this discussion, public housing agencies. The lack of coordination may reflect differences in priorities. Housing is generally not perceived as one of the child welfare system's primary responsibilities, and public schools and departments of workforce development, for example, do not necessarily regard youth aging out of foster care as their target population. As a result, housing assistance is typically not the province of agencies that might otherwise engage in cross-system coordination.

Agencies' failure to establish close working relationships with one another has implications for meeting the housing needs of young people aging out of foster care. Child welfare workers may not be aware of housing programs or resources available to emancipating foster youth because child welfare agencies and local housing authorities often do not work together either to explore housing options for transitioning foster youth or develop plans for housing this population. Thus, even if housing assistance is available, young people aging out of care may need to seek out that assistance and navigate the application process on their own. 


\section{Housing Market}

Local housing market conditions affect the ability of young people to obtain stable housing. In many communities, including the major urban centers that are home to the largest populations of foster youth, safe and affordable rental housing is scarce (GAO 2007). For example, in 2001, a survey of county child welfare directors conducted by the California Department of Social Services identified the need for roughly 3,800 additional subsidized units to house the 4,350 young people who aged out of foster care in fiscal year 2000-2001 (Independent Living Program Policy Unit, Child and Youth Permanency Branch 2002). A subsequent study commissioned by the Foster Youth Housing Initiative determined the need for approximately 700 additional subsidized housing units each year from 2006 to 2010 to accommodate the housing needs of San Francisco Bay Area former foster youth (Latham et al. 2008).

One consequence of the affordable housing shortage is that the housing options available to people aging out of foster care may be limited to the lowest-income, least safe neighborhoods. Housing in these neighborhoods tends to be in poor condition and located far from public transportation or needed services (Center for Public Policy Priorities 2001; Batsche and Reader 2012).

A shortage of affordable housing is not the only barrier faced by young people aging out of foster care. Those who exit from foster care before their 18th birthday cannot legally sign a lease. However, even those who are at least 18 years old and legally permitted to sign a lease, may find that landlords are reluctant to rent to them. Landlords may be skeptical about renting to young people who have neither a history of stable employment nor a good credit history (Center for Public Policy Priorities 2001). The latter can be a significant problem for young people aging out of foster care, many of whom have been the victim of identity theft (California Office of Privacy Protection 2011). Similarly, landlords may be willing to rent to young people only if an adult co-signs the lease or acts as guarantor. Young people aging out of foster care may not know an adult willing to assume that financial responsibility.

Race can also make it difficult for young people aging out of foster care to rent an apartment. Despite laws against racial discrimination in the housing market, audit studies consistently demonstrate persistent discrimination (Turner, Ross, Galster, and Yinger 2002). Given that young people aging out of foster care are disproportionately non-white (Smith and Devore, 2004; Dworsky et al. 2010), discrimination poses a significant problem.

\section{E. What Policies and Programs Address the Housing Needs of Young People Aging Out of Foster Care?}

Over the past three decades, both the federal and state governments have assumed greater responsibility for preparing foster youth for the transition to adulthood and, to a lesser extent, providing support during that transition. The past 30 years have seen growing recognition that young people aging out of care need assistance not only with daily living skills, education, and employment but also with housing. Below, we describe current federal and state policies that address the housing needs of young people aging out of care.

\section{Chafee Foster Care Independence Program}

Authorized by Title I of the 1999 Foster Care Independence Act (PL 106-169) and administered by the Children's Bureau within the U.S. Department of Health and Human Services, 
the Chafee Program doubled the maximum amount of money potentially available to states to $\$ 140$ million and expanded eligibility for services paid for with those funds. Under current law, young people are eligible for Chafee-funded services if they are likely to remain in foster care at least until their 18th birthday, aged out of foster care and are not yet age 21, or exited foster care through adoption or kinship guardianship when they were at least 16 years old.

States have considerable discretion with respect to use of their Chafee funds, although a 20 percent match is required for any funds they draw down. In addition to promoting education, employment, and positive connections with adults, Chafee funds may be used to teach skills that will help youth find and maintain housing once they are on their own. Moreover, whereas states were explicitly prohibited from using their Title IV-E Independent Living Program funds to pay for "room and board," up to 30 percent of Chafee funds may be spent on housing subsidies, transitional housing, independent living stipends, or other housing-related costs.

\section{Education and Training Voucher Program}

In 2001, Congress amended the Foster Care Independence Act by adding the Education and Training Voucher (ETV) Program. The program provides up to $\$ 5,000$ in assistance each year to youth eligible for Chafee-funded services who are attending a qualified postsecondary institution. Youth receiving ETV funds before their 21st birthday remain eligible for the funds until age 23 if they make adequate progress. Although the program's primary purpose is to increase access to postsecondary education and training, ETV funds may pay for housing while recipients are enrolled in school.

Several factors, however, undercut the usefulness of ETV funds in addressing the housing needs of young people exiting from foster care. First, as explained below, most foster youth do not attend college. Second, given that youth in foster care often fall behind in school, those attending college may be older when they enter college and therefore face a problem with ETV eligibility. Third, many foster youth who attend college do not persist to degree completion and therefore do not maintain their eligibility for the ETV Program. Finally, students using ETV funds to pay for housing in college dorms may find themselves homeless during breaks and summer months (Dworsky and Perez 2009).

\section{Fostering Connections to Success and Increasing Adoptions Act}

The Fostering Connections to Success and Increasing Adoptions Act of 2008 introduced several major reforms to federal child welfare policy. Among its many provisions are reforms aimed at increasing educational stability, supporting relative caregivers, and promoting adoption. Although youth aging out of foster care stand to benefit from several of these reforms, they are the target of three reforms in particular. One requires child welfare agencies to help young people develop a personalized transition plan during the 90 days immediately before they age out of foster care. Housing is among the needs the plan must address.

A second, arguably more significant, provision extended the age of eligibility for Title IV-E reimbursement from 18 to 21 year olds beginning in October 2010 if youth are enrolled in school, working at least 80 hours per month, engaged in activities to promote employment and remove barriers to employment, or have a medical condition that precludes any of the above. As a result, states now have a financial incentive to allow young people to remain in foster care until their 21 st birthday. 
A third related provision concerns the definition of child-caring institution. In the past, states were eligible for Title IV-E reimbursement only if an otherwise eligible child was placed in a licensed foster family home or child-caring institution (e.g., group home, residential treatment facility). Recognizing the developmental needs of youth 18 and older, the Fostering Connections Act expanded the definition of child-caring institution to include supervised independent living and granted states considerable discretion with respect to what constitutes a supervised independent living setting, although host homes, college dormitories, shared housing, and semi-supervised and supervised apartments all qualify (U.S. Department of Health and Human Services 2010).

Fourteen states have already passed legislation extending foster care to age 21, and a number of others are contemplating similar action (McCoy-Roth, DeVooght, and Fletcher 2011). Allowing young people to remain in foster care until their 21st birthday could help address their need for safe and affordable housing in at least two ways (Dworsky and Courtney 2010). First, the state would be required to provide young people with an appropriate place to live for up to three additional years. Second, young people may be in a better position to provide for their own housing needs when they are 21 as compared with 18 years old.

Although it is too soon to assess the impact of foster care extended to age 21 on housing stability, a study by Chapin Hall at the University of Chicago found that the lengthened period of foster care was associated with lower rates of homelessness between ages 18 and 21 (although the difference was statistically significant only through age 19). However, the study observed no reduction in the rate of homelessness after age 21 (Dworky and Courtney 2010).

\section{Family Unification Program}

Since 1992, the U.S. Department of Housing and Urban Development's (HUD) Family Unification Program (FUP) has been providing Section 8 Housing Choice Vouchers to families whose children have been placed in foster care, are at imminent risk of foster care placement, or cannot be returned to home because of a lack of adequate housing. In 2000, eligibility for FUP was extended to former foster youth age 18 to 21 whose housing is inadequate and who were at least 16 years old when they exited foster care.

Most FUP vouchers are allocated to eligible youth at the local level, by a public housing agency (PHA), although some state and regional housing authorities may also administer FUP. PHAs and state and regional housing authorities may contract out administration of their FUP to other organizations.

Regardless of arrangement, the public housing entity with an allotment of FUP vouchers is required to partner with the state or local public child welfare agency (PCWA) through a formal memorandum of understanding. Under this agreement, the PCWA's role is to offer the FUP-eligible youth several specified services, including basic life skills training, employment preparation, and educational or career counseling. Responsibility for providing services rests with the state or local child welfare agency with which the public housing agency has partnered. However, the provision of these supportive services may be contracted out to one or more community-based organizations. By contrast, the state or local child welfare agency is not required to provide similar services to FUPeligible families.

Another important distinction between FUP-eligible youth and FUP-eligible families is that the former are limited to a maximum of 18 months of housing assistance (HUD 2010). The 18-month limit does not apply to FUP-eligible families; they may continue to receive assistance as long as they 
meet all other eligibility criteria. Whether the time limit should be viewed as an advantage or a disadvantage is arguable. On the one hand, a young person who aged out of foster care might not be able to make monthly rent payments and, consequently, might be forced to move. From this perspective, the time limit could conceivably contribute to housing instability. On the other hand, the knowledge that housing assistance is limited to 18 months may motivate FUP-eligible youth to concentrate on becoming self-sufficient before their period of eligibility expires. The 18-month limit also means that more young people aging out of foster can benefit from the finite number of available FUP vouchers than if housing assistance were not time-limited.

\section{Public Housing and Section 8 Housing Choice Voucher Program}

Young people aging out of foster care in jurisdictions without an allocation of FUP vouchers, as well as those who are not eligible for or who do not receive a FUP voucher, may benefit from three other HUD programs for low-income individuals and families: the Public Housing Program, the Section 8 Housing Choice Voucher (HCV) Program, and privately owned subsidized housing. Public housing residents live in projects that are typically owned by a local public housing agency. The units are subsidized such that tenants pay rent equivalent to 30 percent of their adjusted gross income. HCV recipients rent housing from landlords or property managers in the private housing market, and the subsidy is paid directly to the landlord or property manager. Like public housing residents, HCV recipients typically pay 30 percent of their adjusted gross income in rent. However, unlike public housing residents, they may live in any housing that meets minimum health and safety standards. Moreover, given that the voucher is attached to the tenant (i.e., tenant-based), it moves with the tenant if the tenant moves. Low-income individuals and families may also live in subsidized apartments that are privately owned (i.e., project-based Section 8). Although tenants pay rent that is also 30 to 40 percent of their adjusted gross income, the voucher is attached to the property (i.e., project-based); if the tenant moves, the voucher does not move with the tenant.

While none of these programs were designed to address the housing needs of young people aging out of foster care, the low incomes of many former foster youth would make them eligible for the programs (Courtney, Dworsky, Lee, and Raap 2010; Courtney and Dworsky 2006; Macomber et al. 2008; Cook et al. 1991; Courtney et al. 2007; Dworsky 2005; Courtney et al. 2001; George et al. 2002). That said, the extent to which the programs can address the housing needs of young people aging out of foster care is limited. In most communities, the demand for housing assistance far exceeds supply. Waiting lists are long or even closed (Turner and Kingsley 2008; Pelletiere and Wardrip 2008), motivating some public housing agencies to identify former foster youth as a preference group. Although young people who receive housing assistance from one of these programs rather than through FUP do not lose eligibility after 18 months, they do not have direct access to the supportive services that former foster youth may need.

\section{Transitional Living Program}

The Transitional Living Program (TLP), administered by the Family and Youth Services Bureau (FYSB), an office within the Administration for Children and Families, funds local and state governments as well as community-based organizations and tribal entities to provide longer-term housing as well as supportive services to homeless youth. Underlying the TLP is the assumption that homeless young people need not only a safe and stable place to live but also basic life skills, education or training, access to physical and mental health care, and close relationships with supportive adults. 
Originally authorized by Congress in 1988 the TLP is currently funded through the Reconnecting Homeless Youth Act of 2008. Grants are awarded competitively to public entities and private organizations for five-year periods and require a 10 percent match. In FY 2009, FYSB awarded grants to 218 local organizations.

TLP grantees are required to provide youth with a safe and stable place to live, which may include host homes, group homes, or supervised apartments. Supervised apartments may be located in agency-owned buildings or rented with assistance from private landlords. Youth must have an individualized case plan that specifies the services they need as well as the steps they must take to transition to independent living or other appropriate housing.

Services, provided directly by TLP grantees or by community-based agencies to which youth are referred, typically include basic life skills training, consumer education, training to improve interpersonal skills and develop positive relationships with peers and adults, education and employment-related services, and physical, mental, and behavioral health care. In addition and consistent with a Positive Youth Development framework, grantees must provide opportunities for youth to exercise leadership and become involved in their communities.

The TLP targets 16 to 21 year olds who are homeless and cannot return home. Youth age 18 and older may remain in the program for up to 540 days (about 18 months) or, in exceptional circumstances, 635 days (about 21 months). Those under age 18 may remain in the program for an additional 180 days or until their 18th birthday, whichever comes first. Young people who have aged out of foster care are eligible for TLP if they are homeless.

\section{State Re-Entry Policies}

Several states that allow young people to remain in foster care until age 21 also offer a re-entry option. That is, young people who choose to exit at age 18, 19, or 20 may voluntarily return to foster care before their 21 st birthday. Half of the 44 states that participated in a recent study of policies and programs to support young people transitioning out of foster care allow re-entry at least under some circumstances (Dworsky and Havlicek 2009). While the policy provides a limited safety net to young people who, for example, find themselves without a place to live, little is known about the number of youth who take advantage of it or their reasons for re-entry.

\section{Continuum of Care}

The Continuum of Care ( $\mathrm{CoC}$ ) refers to the consortium of providers and agencies at the local level that work collectively to address homelessness through a coordinated community-based process of identifying needs, and building a system to address those needs. HUD awards grant funds competitively to Continuums of Care annually to support a range of housing and service programs, including the Supportive Housing Program, the Shelter Plus Care Program, and the Single Room Occupancy Program. Recipients of funds through $\mathrm{CoC}$ programs may choose to design their programs in a way that would allow them to focus on homeless youth ${ }^{5}$.

5 The final rule on the Definition of Homeless defines youth as persons under the age of 25 years of age. Persons served through the $\mathrm{CoC}$ competitive programs must meet the definition of homeless. Persons that are considered at-risk 
(continued)

of homelessness are not eligible to be served under the Continuum of Care programs but are eligible for prevention services through the Emergency Solutions Grants (ESG) program. 


\section{STATE AND LOCAL HOUSING PROGRAMS FOR YOUNG PEOPLE AGING OUT OF FOSTER CARE}

Growing concern about the high rate of homelessness among young people aging out of foster care has led to increased interest in and support for programs that address the housing needs of this particularly vulnerable population. While some of the programs are well-known, others have received little to no attention. As a result, we lack a comprehensive picture of the current range of housing programs targeted to young people aging out of foster care.

To get a fuller sense of how communities are responding to this issue, we conducted an environmental scan and analysis of a range of housing programs serving young people who have aged out of foster care. In this section, we begin with a brief description of the criteria we used to identify relevant programs and a summary of what we learned about them. Next, we present a simple typology of housing programs that emerged from the profiles. We describe each type of housing program and, where relevant, discuss its respective strengths and weaknesses. We conclude with a closer look at a small group of innovative, replicable, and geographically diverse programs that merit further attention.

\section{A. Housing Program Inventory}

We began our environmental scan of programs that serve young people aging out of foster care by casting a wide net. Included in our scan were programs that serve former foster youth exclusively as well as programs that serve former foster youth among other populations (e.g., homeless youth, youth exiting from the juvenile justice system). Although we focused on programs that aim to prevent foster youth from becoming homeless during the transition to adulthood, we note the same programs sometimes also serve young people who have fallen into homelessness.

We excluded several types of housing programs from our scan: programs that serve youth only while they are still in foster care; programs that are no longer in operation; and federal education and job training programs with a residential component, such as Job Corps or the National Guard Youth ChalleNGe. Even though these programs provide participants with housing while they complete their training and education, they do not focus on housing stability after program completion; in addition, they have been the subject of other studies. Finally, we excluded Family Unification Programs (FUP) from our scan because they are currently the focus of other research activities.

As part of a multipronged approach to identify relevant programs, we reviewed:

- Information on the web sites of leading housing and child welfare advocacy organizations, including the Corporation for Supportive Housing, National Alliance to End Homelessness, National Center for Housing and Child Welfare, and California's Evidence-based Clearinghouse for Child Welfare

- Articles published in peer-reviewed journals (e.g., Child Welfare, Children and Youth Services Review, The Prevention Researcher)

- Relevant conference proceedings (e.g., Common Ground's conferences on ending homelessness after foster care) 
This method yielded information on 58 housing programs for foster youth aging out of care. We proceeded to profile these programs along several dimensions of interest, as summarized in Appendix A. Despite considerable effort, it was not possible to obtain complete information about each of the programs. In some cases, the information was not reported or documented, in others it appeared to be outdated or different sources provided contradictory information. In addition, the group of programs we identified does not represent the entire universe of housing programs that serve youth aging out of care. Thus, caution should be used in drawing conclusions from this inventory of housing programs.

Despite these limitations, the programs were sufficiently heterogeneous to make the inventory useful in helping to understand the current landscape. We provide a discussion of each of the key dimensions along which we profiled the programs below, focusing on the ones for which information was the most consistently available:

- Lead agency or agencies

- Program name

- Program location

- Program maturity

- Housing type

- Form of housing assistance

- Funding source(s)

- Youth contribution to rent or savings

- Delivery of supportive services

- On-site supervision

- Participant tracking

- Program evaluation

\section{Lead Agency or Agencies}

Community-based organizations and other nonprofits operate a majority of the programs we profiled, sometimes in conjunction with a housing developer or property management agency. Most of the remaining programs are run by one or more state or local social service, human service, or child welfare agency, although other public sector agencies are occasionally involved.

\section{Target Population ${ }^{6}$}

Many of the profiled housing programs for foster youth have relatively few eligibility requirements. Some serve only young people who aged out of care, including a small number of programs that serve only young people who were still in foster care on their 18th birthday or who

\footnotetext{
${ }^{6}$ Not shown in Appendix Table A.1.
} 
had been in foster care for at least some minimum period of time (typically one year). Other programs are open to a broader population that includes not only former foster youth but youth exiting the juvenile justice system or homeless youth.

The majority of profiled programs serve young people between the ages of 18 and 21. A few serve youth as young as 16; others, including all of the Transitional Housing Program-Plus (THP Plus) programs in California, extend eligibility to age 24 . In addition, eligibility for about half of the programs is time-limited, typically 18 to 24 months.

Although none of the programs served only former foster youth who were pregnant and parenting, a few reserved a certain number of housing units for young custodial parents, and several provided parenting skills training. Likewise, we did not identify any programs that focused exclusively on young people aging out of foster care who report themselves as Lesbian, Gay, Bisexual, or Transsexual (LGBT), and only a small minority mentioned on their web site that they serve the LGBT population. By contrast, a few of the profiled programs specifically target young people aging out of foster care who have mental health problems or other disabilities.

\section{Program Location}

The profiled programs are located in 21 states and the District of Columbia. Some larger states are home to more than one program. Given that the number of young people who aged out of foster care in 2010 varied widely across states - ranging from less than 100 in eight states to over 1,000 in nine states, including California where more than 5,000 young people aged out of foster care (McCoy-Roth, Vooght, and Fletcher 2011) — it is reasonable to expect an unequal distribution of profiled programs across states. In addition, we found that no programs met our criteria in just over half the states, including states where the number of young people who aged out of foster care was relatively high. Not surprisingly, California was home to more profiled programs than any other state. However, we also profiled programs in states where relatively few young people aged out of foster care. Clearly, demand is not the only factor driving program development.

The geographic distribution of profiled programs was heavily skewed toward states on the East and West coasts as well as toward states in the Southwest and Upper Midwest. It is not clear why we found no programs in more than half the states. In some of these states, finding and maintaining housing may be less of a problem for young people aging out of foster care. Alternatively, it could be that FUP or other housing programs excluded from our profile address the housing needs of young people aging out of foster care (McCoy-Roth, Freundlich, and Ross 2011). It is also possible that there is a serious lack of housing programs in these areas for young people aging out of foster care.

As might be expected, programs were located predominantly in major urban areas, perhaps reflecting the concentration of emancipating foster youth. Operating a housing program for such youth may also be more difficult in rural areas.

\section{Program Size and Maturity}

Information about the number of youth served by a program was not always available, but most programs appear to be small. Few have the capacity to serve more than 20 to 30 young people at any one time, perhaps reflecting the programs' relative immaturity. One program began operating as early as 1987 , but the vast majority has been in operation for less than a decade, including one program that began operations in 2011. 


\section{Housing Types}

We used three categories to describe the physical settings in which youth are housed, and some programs provide more than one housing type:

- Clustered or single-site. A single, multi-unit building or group of buildings in which young people are housed.

- Scattered site. Housing dispersed throughout the community and usually rented from a private landlord. Programs that provide monthly rental assistance are assumed to be scattered-site.

- Host homes. A private home headed by a foster family or other single adult who receives a monthly subsidy.

\section{Form of Housing Assistance}

Programs generally assist youth with housing by providing one of the following: (1) a subsidized unit in a building owned and managed by the program; (2) monthly rental assistance in the form of a voucher; or (3) a stipend for living expenses.

\section{Funding Sources}

We distinguished between public and private sources of funding. Public sources include federal, state, and local funds as well as private capital raised through the Low-Income Housing Tax Credit Program. Private sources include grants from foundations and donations from individuals, but not rent or program fees paid by youth.

Almost all of the profiled programs receive at least some public funds. Among the most common public funding sources are federal Chafee dollars, various HUD-administered programs (i.e., Section 811, Section 8 Housing Choice Vouchers, Project-Based Section 8, Supportive Housing, Shelter Plus Care, and the Multifamily Housing Program), and state and local agencies. ${ }^{7}$ Less frequently mentioned public funding streams include low-income housing tax credits, the Homelessness Prevention and Rapid Re-Housing Program (HPRP), the HOME block grant, the Family and Youth Services Bureau's Transitional Living Program, Community Development Block Grants, and funds administered by state housing finance agencies, federal home loan banks, and housing trust funds.

The private sector also helps support many of these programs, including a handful of faithbased programs that did not appear to receive any public funds. These private sector funds came from a variety of sources, including foundations, corporations, the United Way, the Corporation for Supportive Housing, and individual donors.

We noted considerable variation in the number of sources from which programs received funding. Some programs rely on just one or 2 funding sources; others rely on 10 or more. Equally diverse is the way in which funding from different sources has been combined. State funds are

\footnotetext{
7 We counted a program as Chafee-funded if Chafee funds were explicitly mentioned in a list of sources or if a program receives funds from a state or local public child welfare agency.
} 
combined with federal funds, local funds are combined with state funds, and funds from public sources are combined with private funds.

Some programs rely on one set of sources to fund capital development, which includes purchasing, constructing, or rehabilitating housing, and another to fund program operations, such as case management and other supportive services. However, we often could not determine how a particular funding stream was (or had been) used. Similarly, although we found a few references to funds from one source used to leverage funds from another, we discovered that information on leveraging was generally not available for the profiled programs.

\section{Youth Contribution to Rent or Savings}

Most programs require young people to pay at least a minimal amount of rent and/or to contribute to a personal savings account. The rent contribution may be a percentage of income (often 30 percent) or a graduated amount (i.e., increasing to 100 percent of rent) and may differ by housing type within a single program. Among employed youth, the contribution to savings is typically a percentage of income or earnings.

Requiring young people to pay rent or contribute to a savings account is a way to help build self-sufficiency and appears to be the logic behind the graduated approach. Similarly, when young people are required to contribute to a personal savings account, they may use their savings to cover a first month's rent, a security deposit, or other housing costs upon exit from the program.

\section{Delivery of Supportive Services}

As was evident from the earlier discussion of barriers to stable housing, young people aging out of foster care often need a variety of services and supports in order to make a successful transition to adulthood. Many of the profiled programs provide a range of supportive services in addition to case management. Most also make referrals to community-based agencies. Only a few do not include any direct services (defined as case management, supportive services, or referrals to community services).

Among the programs that include a direct service component, we observed substantial variation in the services provided. However, services generally fall into one of four categories: case management services, services to promote self-sufficiency, services to develop independent living skills, and services for special populations.

Case management. All of the profiled programs, with the exception of a few that provide little more than cash assistance for housing, include a case management component. Case management services typically help program participants establish goals and develop a plan to achieve those goals, monitor progress toward goal attainment, and make referrals to communitybased agencies and resources. Programs often require young people to meet regularly with their case manager.

Self-sufficiency. Helping young people become economically self-sufficient is a major goal of many of the profiled programs. To that end, many of the services provided by the programs (or to which young people are referred) aim to promote self-sufficiency. The most common services focus on increasing educational attainment (e.g., tutoring, GED preparation, help with completing college applications, assistance with applying for financial aid) and improving prospects for employment (e.g., job readiness training, help finding employment, or career exploration). In addition, some 
programs require young people to be employed or enrolled in school, often for at least a minimum number of hours each week.

Independent living skills. Most of the profiled programs emphasize basic life skills development. Program participants typically receive training in topics such as budgeting, time management, health, nutrition, hygiene, and conflict resolution. Frequently, a life skills specialist or other program staff member delivers the training. Some of the programs use standardized curricula or hold weekly (and in some cases mandatory) workshops. Among the many independent living skills that programs can help youth develop, financial literacy and money management received the greatest attention.

Needs of special populations. Some programs provide services tailored to the special populations they serve. For example, programs that target young people with mental health problems typically provide individual or group counseling. Although none of the profiled programs exclusively serve pregnant or parenting youth, several operate units specifically for young parents. These programs, as well as others, frequently provide parenting education.

Although we cannot assess the quality of the services provided, programs do appear, by and large, to tailor their services to the needs of individual youth rather than adopt a "one-size-fits-all" approach.

\section{Aftercare Services ${ }^{8}$}

In some respects, all of the profiled programs are aftercare service providers. That is, they provide housing assistance and other supports to young people who have aged out foster care, but relatively few continue to provide some type of assistance to program participants after they exit from a housing program. Aftercare services and support range from help in finding housing, to time-limited housing subsidies, to access to emergency funds when problems arise.

\section{Community Building and Social Supports ${ }^{9}$}

Programs have generally responded in one of two ways to the need for social connections and social support among young people aging out of foster care. One is to include a community-building component as part of the range of program services. Several profiled programs require all program participants to attend a weekly or monthly meeting. Others host social events or organize recreational activities. Not surprisingly, community building is primarily a feature of single-site or clustered-housing programs. Another response is to provide program participants with a mentor, an approach consistent with the belief that young people benefit from a long-term relationship with a caring adult. At least 10 of the profiled programs include some sort of mentoring component.

\footnotetext{
${ }^{8}$ Not shown in Appendix Table A.1

${ }^{9}$ Not shown in Appendix Table A.1.
} 


\section{Program Requirements ${ }^{10}$}

Most of the profiled programs require participants to be employed or in school as well as to pay rent. Many also require young people to participate in life skills training, contribute to a savings plan, or attend community meetings.

We found variation across programs with respect to the number of rules they impose. Some programs require only that participants comply with the conditions of their lease (e.g., prohibitions against playing loud music). Others programs specify long lists of rules that go well beyond "good neighbor" or "good tenant" policies and include curfews, restrictions on guests (particularly overnight), and prohibitions against the consumption of alcohol even among young people who are of legal drinking age.

Several rules might seem outdated or excessive for young adults, but programs may justify some of the rules as necessary for the protection of program participants or as consistent with the doctrine of in loco parentis. Some rules could also be viewed as moral judgments about what young people should or should not do. Programs with the longest lists of rules tend to have a religious affiliation (e.g., The Salvation Army's Booth Brown Foyer).

\section{Program Tracking}

Programs may collect data to track service provision, participation in activities, or youth outcomes. Outcomes may be tracked while youth are in the program or after they leave. However, fewer than half the profiled programs provided information on what outcomes they track or how they track outcomes. ${ }^{11}$ Moreover, both the quality and quantity of the available information varied substantially across programs. At one extreme, programs provided information only on the name of their management information system or noted that case managers track progress toward goals. At the other extreme, programs provided not only a list of the specific outcomes they track but also indicated when and for how long they track those outcomes.

According to the available information, programs appear to collect two types of information for tracking purposes. The first is information on the provision of case management or other services. Some programs use the information to monitor compliance. The second is information on participant outcomes. School enrollment, employment, educational attainment, and exits to permanent housing are the most commonly tracked outcomes. The vast majority of programs that collect such information track only the outcomes of current participants. Relatively few continue to track outcomes after exit, but, when they do, they typically do so for one year. The success of the post-program tracking efforts, however, is unclear.

\footnotetext{
${ }^{10}$ Not shown in Appendix Table A.1

${ }^{11}$ Importantly, the fact that no information about tracking was available for a particular program should not be interpreted as evidence that a program does not engage in tracking. On the contrary, funder reporting requirements would tend to make some type of tracking essential. However, an extensive web-based search turned up no information.
} 
Arguably, the most extensive tracking system is California's THP-Plus Participant Tracking System. ${ }^{12}$ This voluntary web-based statewide data collection system has been in use since FY 20082009 to collect information on the demographic characteristics and outcomes of THP-Plus participants. ${ }^{13}$ Tracked outcomes include housing, employment, assets, education, and criminal justice system involvement. Data are collected at program entry, quarterly while participants are in the program, and at program exit. Additional data are collected 6 and 12 months after participants exit the program to measure longer-term outcomes. Seven of the profiled programs are local versions of THP-Plus.

\section{Program Evaluation}

The effects of the profiled programs have not been rigorously evaluated, although some programs have participated in evaluation activities such as implementation studies and customer satisfaction surveys. We found evidence of or references to an evaluation for only 6 of the 58 profiled programs. Such evidence took the form of information posted on a program's web site, published reports, or articles published in peer-reviewed journals. ${ }^{14}$ We have defined evaluation broadly to include any assessment of program implementation or pre-post outcomes conducted by the program or an outside evaluator. Such a broad definition is important because none of the profiled programs has been evaluated under an experimental or even a quasi-experimental design, and no evaluation included a comparison group of non-participants.

One program (My First Place) is in the midst of a process study conducted by an external evaluator. The study will lay the foundation for a study of program impacts. Another program (Chelsea Foyer) was the focus of an internal evaluation. Two programs (Coolidge Court Apartments and Iowa's Preparation for Adult Living) conduct annual or semi-annual surveys of consumer satisfaction. Two programs (New York/New York III and Transitions Permanent Supportive Housing) were supposed to have been evaluated, but we found no documentation that the evaluations occurred (New York/New York III Supportive Housing Agreement 2005; Technical Assistance Collaborative 2007).

Two recent studies of housing programs for former youth in California may have included a number of the THP-Plus programs we profiled. However, results from both studies were reported in the aggregate rather than separately. One study examined the Foster Youth Housing Initiative (FYHI), a privately funded collaborative effort involving six San Francisco Bay Area nonprofit

12 THP-Plus is a state-funded transitional supportive housing program for former foster youth that provides housing vouchers or payments to providers for up to 24 cumulative months. County child welfare agencies contract with local organizations to operate THP-Plus programs. The programs subsidize the rental costs associated with scatteredsite, single-site, and host-family housing and provide at least 15 required supportive services, either directly or through referral.

13 Programs are not required to use the THP-Plus Participant Tracking System, but they must comply with reporting requirements. Counties participating in the California Connected by 25 Initiative may track the same information about THP-Plus participants through Efforts to Outcomes (ETO), a secure, web-based management information system developed by Social Solutions (CC25I 2011).

14 We found three articles in peer-reviewed journals about the Lighthouse Youth Services Independent Living program. We did not include that program in our inventory because it serves only young people still in foster care. We did not find any articles about its Transitional Living Program, which is included in our inventory and serves emancipated foster youth. 
organizations that provide housing and other services to former foster youth. It collected data from young people who received services from the grantees (186 at baseline and 130 at the 15-month followup) and from service providers (Latham, Drake, Cuevas, and Sugano 2008). ${ }^{15}$ We profiled five of the six grantees. The other California study was based on data reported for 454 young people who exited the THP-Plus program in 31 of the 51 counties with THP-Plus programs during the first three quarters of FY 2010-2011. Even though the counties that contributed data account for approximately two-thirds of all THP-Plus participants, the young people served by the program do not comprise a representative sample of the THP-Plus population. In addition, they are not representative of California's former foster youth population because THP-Plus programs serve only a fraction of the young people who age out of foster care. Moreover, given that the study used a non-experimental design and did not involve a comparison group of non-participants, any changes in participant outcomes cannot be attributed solely to the program (Kimberlin and Lemley 2012).

The lack of rigorous evaluations of housing programs for young people who have aged out of foster care means that that we do not know whether any of the programs prevent homelessness or otherwise reduce housing instability. As long as young people participate in a program, they have stable housing and are not at imminent risk of homelessness. However, it is far from clear that participation in a program helps young people avoid homelessness and remain stably housed after exit.

The data collected by some of the programs as part of their tracking efforts suggest that program participants experience a number of positive outcomes. In particular, at program exit versus program entry, young people are more likely to be enrolled in school, to have earned a high school diploma or GED, and to be employed. The question yet to be answered is whether any of these positive outcomes can be attributed to program participation. It is possible that young people would have experienced similar outcomes had they not participated in the programs.

\section{Challenges Associated with Rigorous Program Evaluation}

It goes without saying that more of the profiled programs should be evaluated. In order to assess programs' long-term effects, the evaluations should involve both process and controlled impact studies and be based on methodologically sound designs. However, several challenges exist to rigorous evaluation of housing programs for young people aging out of foster care.

Sample size. A key challenge is that few programs provide housing to more than two or three dozen young people at a time, and many serve considerably fewer young people. Moreover, programs often have time limits of 12 months or more. A rigorous evaluation would require a long observation period in order to amass a sufficiently large enough sample to detect program impacts.

Post-program mobility. Another challenge is the difficulty in following young people once they leave the program. Programs that provide some type of aftercare services may have more success in tracking young people after exit, but it is unlikely that every participant receives aftercare services, especially those exiting involuntarily.

15 Evaluators planned to conduct seven focus groups with youth and key informant interviews with service providers to contextualize survey findings. Two of the scheduled focus groups did not occur, and one was replaced by three telephone interviews with individual youth. Altogether, fewer than 17 youth participated in the four focus groups. The key informant interviews focused primarily on progress toward capacity-building goals (Latham et al. 2008). 
Willingness or ability to use random assignment. Finally, programs may be unwilling or unable to randomly assign some young people to a control group that would not receive the program's services. Staff may be averse to leaving to chance decisions about who receives program services. When demand for services exceeds program capacity, however, random assignment might be perceived as a fair way to allocate limited resources. In any case, eligibility requirements often translate into a limit on the number of applicants qualified for random assignment.

The recently completed Multisite Chafee Evaluation illustrates the formidability of the above challenges. The Foster Care Independence Act requires the U.S. Department of Health and Human Services to evaluate Chafee-funded independent living programs "deemed to be innovative or of national significance." Researchers from the Urban Institute, Chapin Hall at the University of Chicago, and NORC were contracted to conduct the evaluation.

The researchers considered 87 programs and conducted nearly two dozen site visits as part of an evaluability assessment. They wanted to include a housing program among the sites selected for inclusion and therefore considered several candidates. However, too few young people participated in the programs to allow for random assignment and to provide sufficiently large sample sizes to detect differences between groups (Courtney, Zinn, Koralek, Bess, Stagner, Pergamitt, and Johnson 2011).

Despite such challenges, housing programs must be evaluated to assess their effectiveness. Creative, possibly quasi-experimental techniques are likely to be needed in light of the evaluation challenges presented by the programs. Programs too new for rigorous evaluation may be ripe for implementation studies.

\section{B. A Typology of Youth Housing Programs}

We looked for patterns across programs along several of the most salient dimensions: (1) the physical setting in which youth were housed; (2) the type of housing assistance the program provided; (3) how supportive services were delivered, and (4) whether or not on-site supervision was provided. The patterns we observed across the 58 programs suggested a loose typology in which most programs could be classified as belonging to one of three program types: single-site programs with supervision and supportive services; scatteredsite programs with less supervision and support; and programs that offer several types of housing with varying levels of support and supervision.

\section{Single-Site Programs with Supervision and Supportive Services}

The first type of program is characterized by a clustered or single-site housing model and includes a greater level of supervision and on-site supports than scattered-site models. Subsidized

\section{Restoration Gardens, Baltimore, Maryland Example of Single-Site Program with Supervision and Support}

Restoration Gardens provides single-site housing with supportive services to young people who are currently homeless, who have been homeless within the past five years, and who have aged out of foster care or the juvenile justice system. Restoration Gardens has 40 studio apartments, a common room, computer laboratory, and library. Property management and social service staff are located on site during normal business hours. Three Resident Assistants and one Resident Manager provide round-the-clock supervision and assistance. Residents pay rent equivalent to 30 percent of their adjusted income and receive on-site counseling, job placement, GED preparation and basic life skills training. The program is a partnership of AIDS Interfaith Residential Services, Empire Homes of Maryland, Homes for America, Baltimore Homeless Youth Initiative, and the Baltimore Workforce Investment Board Youth Council. 
apartment units are typically located in a single building or complex or in several buildings on the same street. One unit is usually reserved for a staff person who is available $24 / 7$ to provide supervision and support. Participants may live alone or share a unit with a roommate and are usually required to pay rent.

Case management and other supportive services are often delivered on site, although some services may be provided by contracted community-based agencies. Recreational activities and social events provide frequent opportunities for participants to interact and develop supportive relationships with one another.

Most of the programs provide transitional housing because the buildings are owned by either the agency that runs the program or a housing developer with which the agency partners. That is, young people remain in the units for as long as they participate in the program, usually one to two years, but not beyond. Time limits on participation combined with higher levels of supervision and support may make the programs more appropriate for young people who need a stepping stone toward truly independent living.

\section{Scattered-Site Programs with Less Supervision and On-Site Support}

The second type of program is a scattered-site housing model which tends to provide youth with a lower level of supervision and support than single-site programs. The units are rented from private landlords or property management agencies either directly by the young person or by the agency that operates the housing program. Young people live alone or with a roommate in apartment units spread throughout the community.

Program staff are not on site to provide supervision and support. Instead, young people typically have periodic contact with a case manager who may make home visits as infrequently as once per month or as frequently as more than once per week. Although many of the programs provide some supportive services at a central agency site, young people are often referred to contracted community-based agencies or other resources.

Scattered-site housing may be transitional such that young people remain in their units only as long as they are eligible for rental assistance from the program. However, the housing is often permanent in that young people have the option of remaining in the unit and taking over the lease (if the lease is between the agency and the landlord) when their program participation ends. Such an arrangement can help former foster

\section{Youth Moving On, Milwaukee, Wisconsin \\ Example of Scattered-Site Program with Less \\ Supervision and On-Site Support}

In Milwaukee, Youth Moving On provides scattered-site, single-bedroom apartments and supportive services to former foster youth age 18 to 24 years at risk of homelessness. Administered by St. Aemilian-Lakeside, Inc., and supported by a combination of federal, state, and private funding, the program serves up to 20 youth at one time for a maximum of 18 months. Contributions toward rent increase as young people progress through the program. Participants are offered case management, life skills training, and employment and budgeting assistance, however supportive services are not provided on-site nor are participants supervised at their place of residence. Participants are eligible for an additional subsidy upon successful completion of the program. youth achieve long-term housing stability.

Generally speaking, programs of the second type provide young people with a more mainstream housing experience and may be more conducive to community integration than 
programs that follow a cluster or single-site model. As such, they may be better suited for young people who are more mature or more prepared to live independently.

\section{Programs with Multiple Housing Types and Varying Levels of Supervision and Support}

The third program type is represented by a small number of programs that offer two, or in a few cases, three housing options for youth. Some of the programs offer a combination of cluster and scattered-site housing. Others combine cluster and/or scattered-site housing with host homes (where young people live in the home of an individual or family that receives a monthly subsidy).

It is unclear why some young people are assigned to one type of housing and other young people are assigned to a different type of housing within the same program. Assignment may be based on availability, an assessment of youth needs, or a young person's preferences. Our information sources generally did not distinguish among these possibilities.

Young people living in host homes typically receive supportive services from the agency that runs the housing program or from contracted community-based agencies. Host-home living is

\section{Transitional Housing Program for Emancipating Foster Youth, California Example of Program with Multiple Housing Types and Varying Levels of Supervision and Support}

The Transitional Housing Program for Emancipating Foster Youth is a THP-Plus program that provides housing and supportive services to emancipated foster and probation youth in 11 California counties. The program partners with county agencies, community-based organizations, foundations, and private businesses to provide host family, scattered-site, and single-site housing, depending on the county. Participants receive a wide range of supportive services and must fulfill several requirements, including full-time or part-time employment combined with school or training; work with a life coach and housing specialist; participation in case planning; saving 50 percent of their net earnings; and submitting receipts for food, clothing, and recreational expenditures. Participants are eligible for post-program housing assistance but must agree to maintain contact with the program for at least two years after exit. intended to promote life-long connections with the host family or other caring adults. It provides a situation similar to that experienced by young adults who live with their parents, allowing youth to gain experience in performing tasks of daily living (Sommer et al. 2009). In addition, host homes are believed to provide a cost-effective housing option because they take advantage of existing housing units.

An advantage of programs that combine housing models, and especially the few that offer a true continuum of models (including cluster-site housing, scattered-site housing, and host homes), is that they provide options to young people aging out of foster care. Moreover, young people in the programs may move from one type of housing to another as their needs for supervision and supportive services change. 


\section{Innovative Programs for Further Study}

In addition to developing the typology, we used the profiles to identify a subset of programs that may warrant in-depth study. The programs satisfy three criteria. The first criterion is innovativeness. We defined innovative programs as those that (1) combine components creatively, (2) provide housing assistance and supportive services in a novel way, or (3) rely on a unique mix of funding streams. The second criterion is that programs are replicable; that is, a program lends itself to operation in other sites. Replicability depends on clear specification of a program's core components and program operation that is not linked to conditions or characteristics unlikely to exist in most communities (Metz, Bowie, and Blasé 2007). The third criterion is that they contribute to geographic diversity of the programs.

The 11 programs we identified as meeting our three criteria (Table III.1) share several distinguishing features that merit further study: cross-sector collaboration; blended funding streams; integration of former foster youth with other populations; a unique program philosophy; and colocation of housing with services or employment opportunities.

Table III.1. Innovative Housing Programs for Former Foster Youth

\begin{tabular}{|c|c|c|}
\hline Name & Location & Innovation(s) \\
\hline \multirow{4}{*}{$\begin{array}{l}\text { Affordable Housing } \\
\text { Associates (AHA) } \\
\text { Madison At 14th Street } \\
\text { Apartments }\end{array}$} & \multirow[t]{4}{*}{ Berkeley, CA } & $\begin{array}{l}\text { Subsidized housing for working families with units set aside } \\
\text { for emancipated foster youth }\end{array}$ \\
\hline & & Services delivered on-site and available to all residents \\
\hline & & $\begin{array}{l}\text { Partnership between First Place First Youth, a supportive } \\
\text { services provider, and AHA, an affordable housing developer }\end{array}$ \\
\hline & & Blend of public and private funding streams \\
\hline \multirow{3}{*}{$\begin{array}{l}\text { Interfaith Housing } \\
\text { Development } \\
\text { Corporation of Chicago } \\
\text { Permanent Supportive } \\
\text { Housing Program }\end{array}$} & \multirow[t]{3}{*}{ Chicago, IL } & $\begin{array}{l}\text { Intergenerational approach: Housing and supportive } \\
\text { services provided to former foster youth as well as families } \\
\text { with children being raised by grandparents or other relatives }\end{array}$ \\
\hline & & Two groups of residents act as mutual support networks \\
\hline & & Blend of public and private funding streams \\
\hline \multirow[t]{3}{*}{$\begin{array}{l}\text { Lindquist } \\
\text { Apartments/Life's } \\
\text { Missing Link/RS Eden }\end{array}$} & \multirow[t]{3}{*}{ Minneapolis, MN } & $\begin{array}{l}\text { Collaboration between Life's Missing Link, a supportive } \\
\text { services provider, and RS Eden, an affordable housing } \\
\text { developer }\end{array}$ \\
\hline & & Blend of public and private funding streams \\
\hline & & $\begin{array}{l}\text { Focus on former foster youth with chemical dependency } \\
\text { problems }\end{array}$ \\
\hline \multirow[t]{4}{*}{ Chelsea Foyer } & \multirow[t]{4}{*}{ New York City, NY } & Blend of public and private funding streams \\
\hline & & Based on U.K. Foyer model \\
\hline & & $\begin{array}{l}\text { Partnership among Common Ground, building manager, } \\
\text { Good Shepherd Services, case management and life-skills } \\
\text { training provider, and the Workplace Center at the Columbia } \\
\text { University School of Social Work, which provides workforce } \\
\text { development services. }\end{array}$ \\
\hline & & $\begin{array}{l}\text { Program fee equivalent to } 30 \% \text { of income is deposited into a } \\
\text { savings account until program completion }\end{array}$ \\
\hline \multirow[t]{3}{*}{ Seventh Landing } & \multirow[t]{3}{*}{ St. Paul, MN } & $\begin{array}{l}\text { Partnerships between RS Eden, affordable housing developer, } \\
\text { Growing Home, supportive service providers, and } \\
\text { Corporation for Supportive Housing }\end{array}$ \\
\hline & & $\begin{array}{l}\text { Circle of Courage uses an American Indian medicine wheel to } \\
\text { illustrate a balanced and holistic approach to youth } \\
\text { development }\end{array}$ \\
\hline & & $\begin{array}{l}\text { Emphasis on community-building, resident leadership, and } \\
\text { self-determination }\end{array}$ \\
\hline
\end{tabular}


Table III.1 (continued)

\begin{tabular}{|c|c|c|}
\hline Name & Location & Innovation(s) \\
\hline & & Blend of public and private funding streams \\
\hline & & $\begin{array}{l}\text { On-site coffee shop provides job training and employment } \\
\text { opportunities }\end{array}$ \\
\hline & & $\begin{array}{l}\text { Participation in services is voluntary as long as residents are } \\
\text { not experiencing problems that could compromise their } \\
\text { ability to remain housed }\end{array}$ \\
\hline \multirow[t]{3}{*}{ Restoration Gardens } & \multirow{3}{*}{ Baltimore, MD } & Youth involved in building design \\
\hline & & $\begin{array}{l}\text { Partnership between Empire Homes of Maryland, a subsidiary } \\
\text { of AIRS which owns and manages apartments, and AIRS/CITY } \\
\text { STEPS, which provides supportive services }\end{array}$ \\
\hline & & Blend of public and private funding streams \\
\hline \multirow[t]{5}{*}{ New York/New York III } & \multirow[t]{5}{*}{ New York City, NY } & $\begin{array}{l}\text { Agreement between State and City of NY to create supportive } \\
\text { housing }\end{array}$ \\
\hline & & $\begin{array}{l}\text { Collaboration involving multiple state and local agencies as } \\
\text { well as non-profit housing and service providers }\end{array}$ \\
\hline & & $\begin{array}{l}200 \text { clustered and scattered-site units for former foster } \\
\text { youth and } 200 \text { clustered units for former foster youth with } \\
\text { serious and persistent mental illness }\end{array}$ \\
\hline & & $\begin{array}{l}\text { Clustered units mixed with units for low-income families or } \\
\text { adults }\end{array}$ \\
\hline & & Blend of public and private funding streams \\
\hline \multirow[t]{5}{*}{ Next Steps Collaborative } & \multirow[t]{5}{*}{ Alameda County, CA } & $\begin{array}{l}\text { Collaboration involving Bay Area Youth Centers, Beyond } \\
\text { Emancipation, First Place for Youth and Abode Services' } \\
\text { Project Independence }\end{array}$ \\
\hline & & $\begin{array}{l}\text { Common intake and multi-agency release of information } \\
\text { forms }\end{array}$ \\
\hline & & $\begin{array}{l}\text { Housing options include scattered site housing, community } \\
\text { (i.e., clustered) housing and host homes, depending on the } \\
\text { agency }\end{array}$ \\
\hline & & Bay Area Youth Centers provide mental health services \\
\hline & & $\begin{array}{l}\text { All four agencies provide education and employment } \\
\text { supports }\end{array}$ \\
\hline \multirow[t]{2}{*}{ Edwin Gould Residence } & \multirow[t]{2}{*}{ New York City, NY } & Residence co-located with multi service center \\
\hline & & $\begin{array}{l}\text { Single point of entry for access to services provided by } \\
\text { Exodus Partnership, a collaboration of community-based } \\
\text { agencies }\end{array}$ \\
\hline \multirow[t]{3}{*}{$\begin{array}{l}\text { Youth Supportive } \\
\text { Housing Initiative }\end{array}$} & \multirow[t]{3}{*}{ New Jersey } & $\begin{array}{l}\text { Collaboration involving Department of Children and Families, } \\
\text { the Department of Community Affairs, the Housing and } \\
\text { Mortgage Finance Agency and private sector service } \\
\text { providers }\end{array}$ \\
\hline & & $\begin{array}{l}\text { Service providers do not manage properties and property } \\
\text { managers do not provide services }\end{array}$ \\
\hline & & $\begin{array}{l}\text { Youth and tenant councils provide opportunity for input into } \\
\text { service delivery and housing }\end{array}$ \\
\hline \multirow[t]{3}{*}{$\begin{array}{l}\text { Transitions Permanent } \\
\text { Supportive Housing }\end{array}$} & \multirow[t]{3}{*}{ Albuquerque, NM } & $\begin{array}{l}\text { Collaboration involving public and private partner agencies } \\
\text { Housing-first approach }\end{array}$ \\
\hline & & Consumer choice in housing and services \\
\hline & & Supporting youth to be good tenants (not clients) \\
\hline
\end{tabular}


Cross-sector collaboration. Nearly all the programs listed in Table III.1 involve some type of organizational collaboration. In some cases, it is a formal partnership between an affordable housing developer or property manager and a community-based supportive services provider. Examples include Madison at 14th Street Apartments in Berkeley, California; the two RS Eden programs (i.e., Seventh Landing and Lindquist Apartments in Minnesota); Restoration Gardens in Baltimore, Maryland; and Chelsea Foyer in New York City. In other cases, public and private sector agencies work together. New York/New York III, New Jersey's Youth Supportive Housing Initiative, and the Transitions Permanent Supportive Housing program in Albuquerque, New Mexico, illustrate such an approach. Yet another type of cross-agency collaboration is typified by the Next Steps Collaborative in Alameda County, California. Three of the collaborating agencies operate one housing program (i.e., Beyond Emancipation, First Place for Youth, and Abode Services' Project Independence), and the fourth provides mental health services. Importantly, the agencies use the same intake and multi-agency release of information forms and direct youth to the program that can best meet their needs.

Blended funding streams. Most of the 11 programs we identified as innovative blend funding from a combination of public and private streams. In fact, most of the programs relied on at least eight funding sources. More in-depth study of these programs could reveal how they combine sources to address young people's needs.

Integration of former foster youth with other populations. Most of the programs that follow the clustered or single-site model operate one or more buildings that house only young people who have aged out of foster care. There are, however, a few exceptions. First, the Interfaith Housing Development Corporation of Chicago's Permanent Supportive Housing Program is an intergenerational program that provides housing and supportive services not only to young people who have aged out of foster care but also to families with children in the care of grandparents or other relatives. The intergenerational model posits that the two groups of residents can support one another. Second, the Madison at 14th Street Apartments, operated by Affordable Housing Associates (AHA) in Berkeley, California, provides subsidized housing to low-income families and sets aside units for young people who age out of foster care. Services are provided on site to both the former foster youth and the low-income families. Third, the New York/New York III program operates clustered units for former foster youth with a serious and persistent mental illness. The buildings in which these units are located also house low-income families or adults.

Unique program philosophy. Three of the programs stand out because of their approach to working with young adults about to age out of foster care. The first is Seventh Landing in St. Paul, Minnesota, which strongly encourages self-determination, tenant leadership, and involvement in the community. The Circle of Courage, a philosophy that combines aspects of Native American culture with knowledge gained from research on positive youth development, directs Seventh Street's approach and underscores the value the program places on self-determination. Participation in services is voluntary, unless residents are experiencing problems that could compromise their ability to remain housed.

The second program notable for its approach to young people who have aged out of foster care is New Jersey's Youth Supportive Housing Initiative, which draws a sharp distinction between two of the program's major components. Service providers are not allowed to manage properties, and property managers are not allowed to provide supportive services. The program is also somewhat like Seventh Landing in that youth and tenant councils give residents an opportunity to voice grievances and influence decisions about housing and service delivery. 
The third example of a program distinguished by its approach to working with youth who have aged out of foster care is Transitions Permanent Supportive Housing in Albuquerque, New Mexico. Under the program's Housing First approach, youth receive supportive services only after their housing needs have been addressed. Young people are seen primarily as tenants and only secondarily as recipients of supportive services. Given that the program values individual choice, young people select the rental unit in which they want to live and decide when and if they will participate in supportive services.

Co-location of housing and other services or employment opportunities. It is common for clustered or single-site programs to provide direct services on site. However, the Edwin Gould Residence in New York City is unique in that it is co-located in a multiservice center that provides a single point of entry to services provided by Exodus Partnership, a collaboration of communitybased agencies. Although many of the profiled programs aim to help young people find and maintain employment, they generally do not operate a business that provides youth with jobs. An exception is Seventh Landing in St Paul, Minnesota, where youth may work in an on-site coffee shop owned by the housing developer.

\section{Summary}

The literature reviewed in this report describes the many personal and structural factors that can influence successful transitions to stable housing among young people aging out of foster care. Because of their high risk of homelessness and housing instability, federal and state policies have been implemented to assist this population, but appear to fall short of meeting the need. Our scan of housing programs provides information on how communities try to address this issue. It shows that housing programs for young people aging out of foster care vary along several key dimensions, including the housing model on which they are based, the level of supervision provided, and the availability of on-site supports. Although none of the 58 programs we profiled have been subject to rigorous evaluation, some combine elements in unique ways or adopt other innovative approaches that merit additional study through in-depth descriptive research. In light of the evaluation challenges presented by the programs, any assessment of their effectiveness in providing housing stability to former foster youth will likely depend on the use of creative or quasi-experimental techniques. 


\section{REFERENCES}

Ammerman, S., J. Ensign, R. Kirzner, E. Meininger, M. Tornabene, C. Warf, S. Zerger, and P. Post. "Homeless Young Adults Ages 18-24: Examining Service Delivery Adaptations." Nashville, TN: National Health Care for the Homeless Council, 2004.

Arnett, Jeffrey J. "Emerging adulthood. A theory of development from the late teens through the twenties." American Psychology, vol. 55, no. 5, May 2000, pp. 469-80.

Barth, R. "On their own: The experiences of youth after foster care." Child and Adolescent Social Work, vol. 7, 1990, pp. 419-440.

Batsche, Catherine J., and Steven Reader. "Using GIS to Enhance Programs Serving Emancipated Youth Leaving Foster Care." Evaluation and Program Planning, vol. 35, no. 1, 2012, pp. 25-33.

Berlin, Gordon L., Frank F. Furstenberg, Jr., and Mary C. Waters. "Introducing the Issue." The Future of Children, vol. 20, no. 1, spring 2010, pp 3-18.

Berzin, Stephanie Cosner, Alison M. Rhodes, and Marah A. Curtis. "Housing Experiences of Former Foster Youth: How Do They Fare in Comparison to Other Youth?" Children and Youth Services Review, vol. 33, no. 11, 2011, pp. 2119-126.

Brandford, C. and D. English. "Foster youth transition to independence study." Seattle, WA: Office of Children's Administration Research, Washington State Department of Social and Health Services, 2004.

Brown, Brett, Kristin Moore, and Sharon Bzostek. "A Portrait of Well-Being in Early Adulthood: A Report to the William and Flora Hewlett Foundation." Washington, DC: Child Trends, October 2003.

Brown, S., Wilderson, D. "Homelessness Prevention for Former Foster Youth: Utilization of Transitional Housing Programs." Children and Youth Services Review, vol. 32, no. 10, October 2010, pp. 1464-1472.

Buehler, C., Orme, J. G., Post, J., \& Patterson, D. “The long-term correlates of family foster care." Children and Youth Services Review, vol. 22, no. 8, 2000, pp. 595-625.

Burgard, Sarah, Kristin Seefeldt, and Sarah W. Zelner. "Housing Instability and Health: Findings from the Michigan Recession and Recovery Study." PSC Research Report No. 12-749. January 2012.

Burley, Mason. "Graduation and dropout outcomes for children in state care (2005-2008)." Document No. 09-11-3901. Olympia, WA: Washington State Institute for Public Policy, 2009.

Burley, Mason. "High school graduation and dropout trends for Washington State foster youth (2005-2009)." Document No. 10-10-3901. Olympia, WA: Washington State Institute for Public Policy, 2010. 
California Office of Privacy, "A Better Start: Clearing Up Credit Records for California Foster Children. Report on Results of a Pilot Project." 2011.

Casey Family Programs, "Foster Youth Demonstration Project, Final Evaluation Report." Seattle, WA: Casey Family Programs, July 2008.

Center for Public Priorities, “Texas Foster Care Transitions Project.” 2001.

Cherlin, A.J., E. Scabini, G. Rossi. "Still in the Nest: Delayed Home Leaving in Europe and the United States." Journal of Family Issues, vol. 18, no. 6, 1997, pp. 572-575.

Collins, M. E. Transition to adulthood for vulnerable youths: A review of research and implications for policy. Social Service Review, vol. 75 no. 2, 2001, pp. 271-291.

Collins, Mary Elizabeth and Marah Curtis. "Conceptualizing Housing Careers for Vulnerable Youth: Implications for Research and Policy." American Journal of Orthopsychology, vol. 81, no. 3, 2011, pp. 390-400.

Collins, M.E., Paris, R., and Ward, R. "The permanence of family ties: Implications for youth transitioning from foster care.” American Journal of Orthopsychiatry, vol 78, no. 1, 2008, pp. 54-62.

Cook, R., Fleishman, E., \& Grimes, V. “A national evaluation of Title IV-E foster care independent living programs for youth, Phase 2. (Final Report for Contract No. 105-87-1608)." Rockville, MD: Westat, Inc. 1991.

Corcoran, Mary E. and Ajay Chaudry, "The Dynamics of Childhood Poverty." The Future of Children, vol. 7, no. 2, Summer/Fall 1997, pp. 40-54.

Courtney, M., Piliavin, I., Grogan-Kaylor, A., \& Nesmith, A. "Foster youth transitions to adulthood: A longitudinal view of youth leaving care." Child Welfare, vol. 80, no. 6, 2001, pp. 685-715.

Courtney, Mark, Andrew Zinn, Robin Koralek, Roseana Bess, Matthrew Stagner, Michael Pergamit, Heidi Johnson. "Evaluation of the Independent Living - Employment Services Program, Kern County, California: Final Report. OPRE Report \# 201113." Washington, DC: Office of Planning, Research and Evaluation, Administration for Children and Families, U.S. Department of Health and Human Services, 2011.

Courtney, M.E., Lee, J.A. and Perez, A., "Receipt of help acquiring life skills and predictors of help receipt among current and former foster youth." Children and Youth Services Review, 2011.

Courtney, Mark E., Amy Dworsky, Adam Brown, Colleen Cary, Kara Love, Vanessa Vorhies. Midwest Evaluation of the Adult Functioning of Former Foster Youth: Outcomes at Age 26. Chicago, IL. Chapin Hall Center for Children at the University of Chicago, 2011.

Courtney, Mark E., Amy Dworsky, Gretchen R. Cusick, Judy Havlicek, Alfred Perez, and Thomas Keller. "Midwest evaluation of the adult functioning of former foster youth: Outcomes at age 21." Chicago: Chapin Hall Center for Children at the University of Chicago, 2007. 
Courtney, Mark E., Amy Dworsky, Gretchen R. Ruth, Thomas Keller, Judy Havlicek, and Noel Bost. "Midwest evaluation of the adult functioning of former foster youth: Outcomes at age 19." Chicago: Chapin Hall Center for Children at the University of Chicago, 2005.

Courtney, Mark E., and Amy Dworsky. "Early outcomes for young adults transi-tioning from outof-home care in the U.S.A." Child and Family Social Work, vol. 11, 2006, pp. 209--219.

Courtney, Mark E., and Darcy Hughes-Huering. "The transition to adulthood for youth "aging out" of the foster care system. In On your own without a net: The transi-tion to adulthood for vulnerable populations, edited by D. Wayne Osgood, E. Michael Foster, Constance Flanagan, and Gretchen R. Ruth. Chicago: University of Chicago Press, 2005.

Courtney, Mark E., and Richard P. Barth. "Pathways of older adolescents out of foster care: Implications for independent living services." Social Work, vol. 41, no. 1, 1996, pp. 75-83.

Courtney, Mark E., Irving Piliavin, Andrew Grogan-Kaylor, and Ande Nesmith. "Foster youth transitions to adulthood: A longitudinal view of youth leaving care." Child Welfare, vol. 80, no. 6, 2001, pp.685-717.

Courtney, Mark E., Melissa Roderick, Cheryl Smithgall, Robert Matthew Gladden, and Jenny Nagaoka. "Issue brief: The educational status of foster children." Chicago: Chapin Hall Center for Children at the University of Chicago, 2004.

Courtney, Mark, Amy Dworsky, JoAnn S. Lee, Melissa Rapp. "Midwest Evaluation of the Adult Functioning of Former Foster Youth: Outcomes at Age 23 and 24." Chicago, IL: Chapin Hall at the University of Chicago, 2010.

Courtney, M., Dworsky, A., Brown, A., Cary, C., Love, K., \& Vorhies, V, "Midwest evaluation of the adult functioning of former foster youth: Outcomes at age 26." Chicago, IL: Chapin Hall at the University of Chicago, 2011.

Cusick, G.R., and Courtney, Mark E. "How Do Youth Aging Out of Care Compare with Their Peers?” Chicago, IL: Chapin Hall at the University of Chicago, 2007.

D'Andrade, Amy C., "Placement stability in foster care." In Child welfare for the twenty-first century : a bandbook of practices, policies, and programs, edited by Gerald P. Mallon and Peg McCartt Hess. New York, NY: Columbia University Press, 2005.

Davis, R. J. "College access, financial aid and college success for undergraduates from foster care." Washington, DC: National Association of Student Financial Aid Administrators, 2006.

Day, Angelique., Amy Dworsky, Kieran Fogarty and Amy Damashek. "An examination of postsecondary retention and graduation among foster care youth enrolled in a four-year university." Children and Youth Services Review, 2011.

DeWoody M, Ceja K, Sylvester M. "Independent living services for youths in out-of-home care." Washington, DC: Child Welfare League of America, 1993. 
Donkoh, Charles, Kristen Underhill, Paul Montgomery. "Independent living programmes for improving outcomes for young people leaving the care system." Campbell Systematic Reviews, vol. 8, 2006.

Duncan, Greg J., and Jeanne Brooks-Gunn. Consequences of Growing up Poor. New York: Russell Sage Foundation, 1997.

Dworsky, Amy, and Judy Havlicek. "Experiences of Foster Youth in an Employment Training and Job Placement Program.” Chicago, IL: Chapin Hall at the University of Chicago, 2010.

Dworsky, Amy and Judy Havlicek. "Review of State Policies and Programs to Support Young People Transitioning Out of Foster Care." Chicago, IL: Chapin Hall at the University of Chicago, 2009.

Dworsky, Amy. "The economic self sufficiency of Wisconsin's former foster youth." Children and Youth Services Review, vol. 27, 2005, pp. 1085-1118.

Dworsky, Amy, Catherine Roller White, O'Brien, Kirk, Peter Pecora, Mark Courtney, Ronald Kessler, Nancy Sampson and Irving Hwang. "Racial and ethnic differences in the outcomes of former foster youth." Children and Youth Services Review, vol. 32, no. 6, 2010, pp. 902-912.

Dworsky, Amy, and Alfred Perez. "Helping former foster youth graduate from college through campus support programs." Children and Youth Services Review, vol. 32, no. 2, 2010, pp. 255-263.

Dworsky, Amy and Mark Courtney. "Assessing the Impact of Extending Care beyond Age 18 on Homelessness: Emerging Findings from the Midwest Study.” Chicago, IL. Chapin Hall at the University of Chicago, March 2010.

Dworsky, Amy, and Mark Courtney. "Homelessness and the transition from foster care to adulthood among 19 year old former foster youth." Child Welfare, vol. 88, no. 4, 2009, pp. 23-56.

Dworsky, A. \& Courtney, M. E. “The risk of teenage pregnancy among transitioning foster youth: Implications for extending state care beyond age 18." Children and Youth Services Review, vol. 32, no. 10, 2010, pp. 1351-1356.

Dworsky, Amy. "The Transition to Adulthood Among Youth "Aging Out" of Care: What Have We Learned?" In Child Welfare Research: Advances for Practice and Policy, edited by Duncan Lindsey and Aron Shlonsky. New York, NY: Oxford UP, 2008.

Fanshel, David. "Foster Care as a two-tier system." Children and Youth Services Review, vol. 14, 1992, pp. 49-60.

Feldmann, Jennifer and Amy A. Middleman. "Homeless adolescents: common clinical concerns." Seminars in Pediatric Infectious Disease, vol. 14, no. 1, 2003, pp. 6-11.

Festinger, Trudy. "No one ever asked us: A postscript to forever care." New York, NY: Columbia University Press, 1983. 
Fields, Jason. "Children’s living arrangements and characteristics: March 2002," Current Population Report No. P20-547. Washington, DC: U.S. Bureau of the Census, 2003.

Fowler, P. J., P. A. Toro, C. J. Tompsett, and K. Hobden. "Youth aging out of foster care in southeast Michigan: A follow-up study." Paper presented to the Michigan Department of Human Services, Wayne State University, Detroit, MI, 2006.

Fowler, Patrick. J., Paul . A. Toro, and Bart. W. Miles. "Pathways to and From Homelessness and Associated Psychosocial Outcomes Among Adolescents Leaving the Foster Care System." American Journal of Public Health, vol. 99, no 8, 2009, pp. 1453-458.

George, Robert M., Lucy Bilaver, Bong Joo Lee, Barbara Needell, Alan Brookhard, William Jackman, "Employment Outcomes for Youth Aging Out of Foster Care Final Report," Chicago, IL: University of Chicago Chaplin Center for Children, March 2002.

Goldscheider, F. and C. Goldscheider. The Changing Transition to Adulthood. Leaving and Returning Home. Thousand Oaks, CA: Sage, 1999.

Gotbaum, B. "Children raising children: City fails to adequately assist pregnant and parenting youth in foster care.” New York, NY: Public Advocate for the City of New York, 2005.

Government Accountability Office. "African American Children in Foster Care: Additional HHS Assistance Needed to Help States Reduce the Proportion in Care.” Report Number GAO-07816. Washington, DC: GAO, 2007.

Granovetter, M. S. Getting a job: A study of contacts \& careers (2nd ed.). Chicago, IL: The University of Chicago Press, 1995.

Halley, M., and A. English. "Health Care for Homeless Youth: Policy Options for Improving Access." San Francisco, CA: Center for Adolescent Health \& the Law and the Public Policy Analysis and Education Center for Middle Childhood, Adolescent and Young Adult Health at the University of California San Francisco, 2008.

Hines, A.M., J. Merdinger, and P. Wyatt, "Former foster youth attending college: resilience and the transition to young adulthood." American Journal of Orthopsychiatry, vol. 75, no. 3, 2005, pp. 381394.

Hyde, J., and N. Kammerer. “Adolescents' perspective on placement moves and congregate settings: complex and cumulative instabilities in out-of-home care." Children and Youth Services Review, vol. 31, 2009, pp. 265-273.

Independent Living Program Policy Unit, Child and Youth Permanency Branch. "Report on the Survey of the Housing Needs of Emancipated Foster/Probation Youth.” 2002.

Johnson, G.. Natalier, K., Mendes, P., Liddiard, M., Thoresen, S., Hollows, A. and Bailey, N. "Pathways from out-of-home care." AHURI Final Report No.147. Melbourne, Australia: Australian Housing and Urban Research Institute, 2010. 
Jones, M. A., and B. Moses, West Virginia's former foster children: Their experiences in care and their lives as young adults. Washington, DC: Child Welfare League of America, 1984.

Keller T.E., G.R. Cusick, M.E. Courtney. "Approaching the transition to adulthood: distinctive profiles of adolescents aging out of the child welfare system." Social Service Review, vol. 81, no. 3, 2007, pp. 455-484.

Keller, T.E., Salazar, A., \& Courtney, M.E. "Prevalence and timing of diagnosable mental health, alcohol, and substance use problems among older adolescents in child welfare systems." Children \& Youth Services Review, vol. 32, 2010, pp. 626-634.

Kimberlin, Sara and Amy Lemley. "Policy Brief: Demographics and Outcomes of THP-Plus Participants: Implications for Extended Foster Care in California." San Francisco, CA: John Burton Foundation, January 2012.

Kushel M.B., J.A. Hahn, J.L. Evans, D.R. Bangsberg, and A.R. Moss. "Revolving doors: imprisonment among the homeless and marginally housed population." American Journal of Public Health, vol 85, 2005, pp. 1747-1752.

Kushel, M.B., I.H. Yen, L. Gee, M.E. Courtney. "Homelessness and Health Care access after emancipation: results for the Midwest evaluation of adult functioning of former foster youth." Archives of Pediatric Adolescent Medicine, vo. 161, no. 10, October 2007, pp. 986-93.

Latham, Nancy, Emily Boer Drake, Rachel Cuevas, and Eiko Sugano. "Foster Youth Housing Initiative: Final Evaluation Findings." San Francisco, CA: LaFrance Associates, November 2008.

Lin, Nan. "Social Networks And Status Attainment." Annual Review of Sociology, vol. 25, no. 1, 1999, pp. 467-87.

MacArthur Foundation, "How Housing Matters to Families and Communities." http://www.macfound.org/site/c.1kLXJ8MQKrH/b.6547265/k.4E11/About_the Initiative.htm

Macomber, J., S. Cuccaro Alamin, D. Duncan, M. McDaniel, T. Vericker, M. Pergamit, B. Needell, H. Kum, J. Stewart, C. Lee, and R. Barth. "Coming of age: Empirical outcomes for youth who age out of foster care in their middle twenties." Washington, DC: U.S. Department of Health and Human Services, 2008.

McCoy-Roth, Marci, Kerry DeVooght, and Megan Fletcher. "Number of Youth Aging Out of Foster Care Drops below 28,000 in 2010.” Fostering Connections, 2011.

McMillen, J. Curtis, and Jayne Tucker. "The status of older adolescents at exit from out-of-home care." Child Welfare, vol. 78, 1999, pp. 339-360.

Mech, E. "Uncertain futures: Foster youth in transition to adulthood." Washington, DC: Child Welfare League of America, 2003. 
Metz, Allison J.R., Lillian Bowie, and Karen Blasé. "Seven Activities for Enhancing the Replicability of Evidence-Based Practices,” Washington, DC: Child Trends, October 2007.

Naude, Alice, Corinne Le'Tourneau, Lisa Falcocchio. "Ending Homelessness After Foster Care." Proceedings of Common Ground's Ending Homelessness After Foster Care Conference Report. New York, NY: Common Ground, 2009.

Needell, B., S. Cuccaro-Alamin, A. Brookhart, W. Jackman, W., and A. Shlonsky. "Youth emancipating from foster care in California: Findings using linked administrative data." Berkeley, CA: Center for Social Services Research, University of California, Berkeley, 2002.

New York City Department of Housing, "New York/New York III Supportive Housing Agreement." New York, NY. 2005. [city regulation: http://www.nyc.gov/html/doh/downloads/pdf/dmh/dmh-housing-agreement.pdf]

Osgood, D. W., E. M. Foster, and M.E. Courtney. "Vulnerable populations and the transition to adulthood.” The Future of Children, vol. 20, no. 1, 2010, pp. 209-229.

Pecora, P., R. Kessler, J. Williams, K. O’Brien, A.C. Downs, D. English, J. White, E. Hiripi, C. White, T. Wiggins, and K. Holmes. "Improving family foster care: Findings from the Northwest Foster Care Alumni Study.” Seattle, WA: Casey Family Programs, 2005.

Pecora, P., J. Williams, R. Kessler, A.C. Downs, K. O’Brien, E. Hiripi, and S. Morello. "Assessing the effects of foster care: Early results from the Casey National Alumni Study," Seattle, WA: Casey Family Programs, 2003.

Pelletiere, D., and K. Wardrip. "Renters and the housing credit crisis." Poverty and Race, vol. 17, 2008, pp. 3-7.

Pevalin, D.J. "Housing repossessions, evictions and common mental illness in the UK: results from a household panel study." Journal of Epidemiology \& Community Health, vol. 63, 2009, pp. 949-951.

Phinney, Robin, Sheldon Danziger, Harold Pollack, and Kristin Seefeldt. "Housing Instability among Current and Former Welfare Recipients." American Journal of Public Health, vol. 97, no. 5, 2007.

Reid, K.W., E. Vittinghoff, and M.B. Kushel. "Association between the level of housing instability, economic standing, and health care access: A meta-regression." Journal of Health Care for the Poor and Underserved, vol. 19, no. 4, 2008, pp. 1212-1228.

Reilly, Thom. "Transition from Care: Status and Outcomes of Youth Who Age Out of Foster Care." Child Welfare, vol. 82, no. 6, 2003, pp. 727-46.

Schoeni, R. and K. Ross. "Material assistance received from families during the transition to adulthood." In On the frontier of adulthood: Theory, research, and public policy. Edited by R. Settersten, Jr., F. Furstenberg, Jr., \& R. Rumbaut. Chicago, IL: University of Chicago Press, 2004.

Settersten, Richard A, Frank F. Furstenberg, and Ruben G. Rumbaut. On the Frontier of Adulthood: Theory, Research, and Public Policy. Chicago, IL: University of Chicago Press, 2005. 
Settersten, Richard A. Jr., and Barbara Ray. "What's Going on with Young People Today? The Long and Twisting Path to Adulthood." The Future of Children, vol 20, no 1, Spring 2010, pp. 19-41.

Shanahan, Michael J. "Pathways to Adulthood in Changing Societies: Variability and Mechanisms in Life Course Perspective." Annual Review of Sociology, vol. 26, no. 1, 2000, pp. 667-92.

Singer, A. "Assessing outcomes of youth transitioning from foster care." Salt Lake City, UT: Department of Human Services, 2006.

Smith, Carrie, and Wynette Devore. "African American Children in the Child Welfare and Kinship System: From Exclusion to over Inclusion." Children and Youth Services Review vol. 26, no. 5, 2004, pp. 427-46.

Sommer, Heidi, Lynn Wu, and Jane Mauldon. "California Connected by 25: Efforts to Address the Housing Needs of Transitioning Foster Youth." Berkeley, CA: CC251 Systems Change Assessment Team, February 2009.

Sum, Khatiwada and Palma. "The Continued Collapse of the Nation's Teen Summer Job Market: Who Worked in the Summer of 2011?”" Center for Labor Market Studies, 2011.

Technical Assistance Collaborative. "New Mexico Behavioral Health Purchasing Collaborative Long Range Supportive Housing Plan.” New Mexico, 2007.

Toro, Paul A., Amy Dworsky, and Patrick J. Fowler. "Homeless youth in the United States: Recent research findings and intervention approaches. 2007 National Symposium on Homeless Research" Washington, DC: Office of the Assistant Secretary of Planning and Evaluation, U.S. Department of Health and Human Services and the Office Policy, Development, and Research, U.S. Department of Housing and Urban Development, 2007.

Turner, Margery Austin, and G. Thomas Kingsley. "Federal Programs for Addressing Low-Income Housing Needs_-A Policy Primer.” Washington, DC: The Urban Institute, 2008.

Turner, Margery A., Stephen Ross, George C. Galster, and John Yinger, "Discrimination in Metropolitan Housing Markets: National Results from Phase 1 of the Housing Discrimination Study (HDS)," Working papers 2002-16, Storrs, CT: University of Connecticut, Department of Economics. 2002.

U.S. Department of Health and Human Services Administration for Children and Families. "Guidance on Fostering Connections to Success and Increasing Adoptions Act of 2008." Washington, DC: DHHS ACF. Log No. ACYF-CB-PI-10-11, 2010.

U.S. Department of Health and Human Services, Health Resources and Services Administration. "Program Assistance Letter: Understanding the Health Care Needs of Homeless Youth." Washington, DC: DHHS, 2001.

U.S. Department of Health and Human Services, Administration for Children and Families. “AFCARS Report: Preliminary FY 2011 Estimates as of June 2011.” Washington, DC: DHHS ACF, 2011. 
U.S. Department of Housing and Urban Development, "Family Unification Program." http://portal.hud.gov/hudportal/HUD?src=/program_offices/public_indian_housing/progra $\mathrm{ms} / \mathrm{hcv} /$ family

U.S. Department of Labor, Bureau of Labor Statistics. "The Employment Situation - December 2011.” News Release Number USDL-12-0012. Washington, DC: DOL BLS, 2011.

U.S. Government Accountability Office. "HHS actions could improve coordination of services and monitoring of states' independent living programs." Report no. GAO-05-25. Washington, D.C.: GAO, 2004.

U.S. Government Accountability Office. "HHS Actions would help states prepare youth in the foster care for independent living." Report no. GAO-07-1097T. Washington, DC: GAO, 2007.

U.S. Government Accountability Office. "Foster care: effectiveness of independent living services unknown." Report no. HEHS-00-13. Washington, D.C.: GAO, 1999.

Vaughn, Michael G., Jeffrey J. Shook, and J. Curtis McMillen. "Aging out of foster care and legal involvement: Toward a typology of risk." Social Service Review, vol. 82, 2008, pp. 419-446.

Vaughn, Michael G., Marcia T. Ollie, J. Curtis McMillen, Lionel D. Scott, and Michelle R. Munson. "Substance use and abuse among older youth in foster care." Addictive Behaviors, vol. 32, 2007, pp. 1929-1935.

Wade, J., J. Dixon, "Making a home, finding a job: investigating early housing and employment outcomes for young people leaving care." Child and Family Social Work, vol. 11, 2006, pp. 199208.

Whitbeck, L., D. Hoyt, K. Yoder, A. Cauce, and M. Paradise. "Deviant behavior and victimization among homeless and runaway adolescents." Journal of Interpersonal Violence, vol. 16, 2001, pp. 1175-1204.

White, Catherine Roller, Anne H. Gallegos, Kirk O'Brien, Susan Weisberg, Peter J. Pecora, and Rebecca Medina. "The Relationship Between Homelessness and Mental Health Among Alumni of Foster Care: Results From the Casey Young Adult Survey." Journal of Public Child Welfare, vol. 5, no. 4, 2011, pp. 369-89.

Wight, Vanessa R., Michelle Chau, Yumiko Aratani, Susan Wile Schwarz, and Kalyani Thampi. "A Profile of Disconnected Young Adults in 2010.” New York, NY: National Center for Children in Poverty Mailman School of Public Health Columbia University, 2010.

Wolanin, T. R. Higher education opportunities for foster youth: A primer for policymakers. Washington, DC: Institute for Higher Education Policy, 2005.

Wulczyn Fred H. "Foster Youth in Context." In Achieving Permanence for Older Children and Youth in Foster Care. Edited by Kerman Benjamin, Freundlich Madelyn, and Maluccio Anthony N., New York, NY: Columbia University Press, 2009. pp. 13-31. 
Wulczyn, F., Hislop, K., and Chen, L. "Adoption dynamics: An update on the impact of the Adoption and Safe Families Act.” Chicago: Chapin Hall Center for Children, 2005.

Wulczyn, F., K.B. Hislop, and R.M. Goerge, "Foster care dynamics 1983-1998." Chicago, IL: Chapin Hall Center for Children, 2001.

Yelowitz, A. "Young adults leaving the nest: The role of cost-of-living." In The price of independence: The economics of early adulthood, edited by S. Danziger and C. Rouse. New York, NY: Russell Sage Foundation, 2007. 
APPENDIX A

INVENTORY OF SELECTED HOUSING PROGRAMS FOR YOUTH

AGING OUT OF FOSTER CARE 



\begin{tabular}{|c|c|c|c|c|c|c|c|c|c|c|c|}
\hline $\begin{array}{l}\text { Lead Agency or } \\
\text { Agencies }\end{array}$ & Program Name & State & $\begin{array}{l}\text { Start } \\
\text { Date }\end{array}$ & Housing Type & $\begin{array}{l}\text { Form of } \\
\text { Housing } \\
\text { Assistance }\end{array}$ & $\begin{array}{l}\text { Funding } \\
\text { Source }\end{array}$ & $\begin{array}{l}\text { Required } \\
\text { Contribution } \\
\text { to Rent or } \\
\text { Savings }\end{array}$ & $\begin{array}{l}\text { Delivery of } \\
\text { Supportive } \\
\text { Services }\end{array}$ & $\begin{array}{c}\text { On-Site } \\
\text { Supervision }\end{array}$ & $\begin{array}{l}\text { Participant } \\
\text { Tracking }\end{array}$ & $\begin{array}{l}\text { Program } \\
\text { Evaluation }\end{array}$ \\
\hline New Leaf & $\begin{array}{l}\text { Empower } \\
\text { Transitional Living } \\
\text { Program }\end{array}$ & $A Z$ & By 2010 & $\begin{array}{l}\text { Clustered; } \\
\text { Scattered Site }\end{array}$ & $\begin{array}{l}\text { Subsidized Unit } \\
\text { (C) } \\
\text { Monthly Rental } \\
\text { Assistance (S) }\end{array}$ & Private & $\mathrm{R}$ & CM; services & NA & $\begin{array}{l}\text { During } \\
\text { participation }\end{array}$ & NA \\
\hline Abode Services & $\begin{array}{l}\text { Project } \\
\text { Independence (THP- } \\
\text { Plus) }^{\mathrm{b}}\end{array}$ & CA & 2000 & Scattered Site & $\begin{array}{l}\text { Monthly Rental } \\
\text { Assistance }\end{array}$ & Both & R - Grad & $\begin{array}{l}\text { CM; off-site } \\
\text { services }\end{array}$ & None & $\begin{array}{l}\text { During } \\
\text { participation } \\
\text { and after } \\
\text { exit } \\
\text { program. }\end{array}$ & NA \\
\hline $\begin{array}{l}\text { Affordable Housing } \\
\text { Associates (AHA) }\end{array}$ & $\begin{array}{l}\text { AHA's Madison at } \\
\text { 14th Street }\end{array}$ & CA & 2008 & Clustered & Subsidized Unit & Both & $\mathrm{R}$ & $\begin{array}{l}\text { On-site } \\
\text { services; } \\
\text { referrals }\end{array}$ & NA & NA & NA \\
\hline $\begin{array}{l}\text { Alameda County } \\
\text { Independent Living } \\
\text { Skills Program }\end{array}$ & $\begin{array}{l}\text { Independent Living } \\
\text { Skills Program } \\
\text { Housing Grants for } \\
\text { Emancipated Youth }\end{array}$ & CA & 1987 & Scattered Site & $\begin{array}{l}\text { Stipend (up to } \\
\$ 1,000 \\
\text { lifetime) }\end{array}$ & Public & $\mathrm{R}$ & None & None & NA & NA \\
\hline Aspiranet & $\begin{array}{l}\text { Transitional Housing } \\
\text { Program for } \\
\text { Emancipating Foster } \\
\text { Youth (THP-Plus) }\end{array}$ & CA & NA & $\begin{array}{l}\text { Clustered } \\
\text { Scattered Site } \\
\text { Host Homes }\end{array}$ & $\begin{array}{l}\text { Subsidized Unit } \\
\text { (C) } \\
\text { Monthly Rental } \\
\text { Assistance (S, } \\
\text { H) }\end{array}$ & Public & $\begin{array}{l}\text { S- } 50 \% \text { of } \\
\text { income }\end{array}$ & $\begin{array}{l}\text { On-site } \\
\text { services; CM }\end{array}$ & NA & NA & NA \\
\hline $\begin{array}{l}\text { Beyond } \\
\text { Emancipation }\end{array}$ & $\begin{array}{l}\text { Beyond } \\
\text { Emancipation (THP- } \\
\text { Plus) }\end{array}$ & CA & By 2006 & $\begin{array}{l}\text { Clustered; } \\
\text { Host Homes }\end{array}$ & $\begin{array}{l}\text { NA (C) } \\
\text { Stipend }(H)\end{array}$ & Public & $\mathrm{R}$ & $\begin{array}{l}\text { On-site and } \\
\text { off-site } \\
\text { services; CM; } \\
\text { referrals; }\end{array}$ & NA & NA & NA \\
\hline Bill Wilson Center & $\begin{array}{l}\text { Bill Wilson Center } \\
\text { Transitional Housing } \\
\text { Program (THP-Plus) }\end{array}$ & CA & NA & Scattered Site & NA & Both & None & $\mathrm{CM}$ & YES & $\begin{array}{l}\text { During } \\
\text { participation } \\
\text { and at exit }\end{array}$ & NA \\
\hline First Place for Youth & $\begin{array}{l}\text { My First Place (THP- } \\
\text { Plus) }^{b}\end{array}$ & CA & 1998 & $\begin{array}{l}\text { Clustered } \\
\text { Scattered Site } \\
\text { Host Homes }\end{array}$ & $\begin{array}{l}\text { Monthly Rental } \\
\text { Assistance (C, } \\
\text { S) } \\
\text { Stipend for } \\
\text { "host" (H) }\end{array}$ & Both & R - Grad & CM; Services & None & $\begin{array}{l}\text { During } \\
\text { participation } \\
\text { and after } \\
\text { exit }\end{array}$ & $\begin{array}{l}\text { Ongoing } \\
\text { implement } \\
\text { ation } \\
\text { evaluation } \\
\text { by P/PV. }\end{array}$ \\
\hline $\begin{array}{l}\text { Fred Finch Youth } \\
\text { Center }\end{array}$ & $\begin{array}{l}\text { Coolidge Court } \\
\text { Apartments }\end{array}$ & CA & 1998 & Clustered & Subsidized Unit & Both & $\begin{array}{l}\mathrm{R}-30 \% \text { of } \\
\text { Income }\end{array}$ & $\begin{array}{l}\text { On-site } \\
\text { services; CM }\end{array}$ & YES & $\begin{array}{l}\text { During } \\
\text { participation }\end{array}$ & $\begin{array}{l}\text { Annual } \\
\text { internal } \\
\text { consumer } \\
\text { satisfaction } \\
\text { survey }\end{array}$ \\
\hline Hillsides & $\begin{array}{l}\text { Youth Moving On } \\
\text { Transitional Housing } \\
\text { (Pasadena) }\end{array}$ & CA & 2006 & Clustered & Subsidized Unit & Private & NA & $\begin{array}{l}\text { On-site } \\
\text { services }\end{array}$ & YES & NA & NA \\
\hline
\end{tabular}




\begin{tabular}{|c|c|c|c|c|c|c|c|c|c|c|c|}
\hline $\begin{array}{l}\text { Lead Agency or } \\
\text { Agencies }\end{array}$ & Program Name & State & $\begin{array}{l}\text { Start } \\
\text { Date }\end{array}$ & Housing Type & $\begin{array}{l}\text { Form of } \\
\text { Housing } \\
\text { Assistance }\end{array}$ & $\begin{array}{l}\text { Funding } \\
\text { Source }\end{array}$ & $\begin{array}{l}\text { Required } \\
\text { Contribution } \\
\text { to Rent or } \\
\text { Savings }\end{array}$ & $\begin{array}{l}\text { Delivery of } \\
\text { Supportive } \\
\text { Services }\end{array}$ & $\begin{array}{c}\text { On-Site } \\
\text { Supervision }\end{array}$ & $\begin{array}{l}\text { Participant } \\
\text { Tracking }\end{array}$ & $\begin{array}{l}\text { Program } \\
\text { Evaluation }\end{array}$ \\
\hline Larkin Street & $\begin{array}{l}\text { Larkin Street } \\
\text { Extended Aftercare } \\
\text { for Supported } \\
\text { Emancipation } \\
\text { (LEASE) (THP-Plus) }\end{array}$ & CA & 2003 & Scattered Site & $\begin{array}{l}\text { Monthly Rental } \\
\text { Assistance }\end{array}$ & Public & $\begin{array}{l}\mathrm{R}-30 \% \text { of } \\
\text { Income }\end{array}$ & $\begin{array}{l}\mathrm{CM} \text {; services; } \\
\text { referrals }\end{array}$ & None & $\begin{array}{l}\text { During } \\
\text { participation }\end{array}$ & NA \\
\hline Larkin Street & $\begin{array}{l}\text { Larkin Street } \\
\text { Holloway House }\end{array}$ & CA & 2007 & Clustered & Subsidized Unit & Public & NA & $\mathrm{CM}$ & YES & $\begin{array}{l}\text { During } \\
\text { Participation }\end{array}$ & NA \\
\hline $\begin{array}{l}\text { Lutheran Social } \\
\text { Services of Northern } \\
\text { California }\end{array}$ & $\begin{array}{l}\text { LaVerne Adolfo } \\
\text { Permanent } \\
\text { Supportive Housing } \\
\text { Program (THP-Plus) }\end{array}$ & $\mathrm{CA}$ & NA & Scattered Site & $\begin{array}{l}\text { Monthly Rental } \\
\text { Assistance }\end{array}$ & Public & $\mathrm{R}$ & $\begin{array}{l}\text { On-site } \\
\text { services }\end{array}$ & NA & NA & NA \\
\hline $\begin{array}{l}\text { Orangewood } \\
\text { Children's } \\
\text { Foundation }\end{array}$ & $\begin{array}{l}\text { Rising Tide } \\
\text { Communities (THP- } \\
\text { Plus) }\end{array}$ & $\mathrm{CA}$ & 1999 & Clustered & Subsidized Unit & Both & R -Grad; S & Services & NA & $\begin{array}{l}\text { During } \\
\text { participation }\end{array}$ & NA \\
\hline $\begin{array}{l}\text { United Friends of } \\
\text { the Children }\end{array}$ & $\begin{array}{l}\text { Pathways } \\
\text { Transitional Living } \\
\text { Program (THP-Plus) }\end{array}$ & $\mathrm{CA}$ & 2002 & Clustered & Subsidized unit & Private & $\begin{array}{l}\mathrm{R}-30 \% \text { of } \\
\text { Income }\end{array}$ & $\begin{array}{l}\text { On-site } \\
\text { services }\end{array}$ & YES & $\begin{array}{l}\text { During } \\
\text { participation } \\
\text { and after } \\
\text { exit }\end{array}$ & NA \\
\hline $\begin{array}{l}\text { Volunteers of } \\
\text { America of Greater } \\
\text { Sacramento \& } \\
\text { Northern Nevada }\end{array}$ & $\begin{array}{l}\text { LaVerne Adolfo } \\
\text { Transitional Housing } \\
\text { Program (THP-Plus) }\end{array}$ & $\mathrm{CA}$ & NA & Clustered & NA & Public & NA & Services & NA & NA & NA \\
\hline $\begin{array}{l}\text { Connecticut } \\
\text { Department of } \\
\text { Children and Family } \\
\text { Services }\end{array}$ & $\begin{array}{l}\text { Connecticut's } \\
\text { Community Housing } \\
\text { Assistance Program }\end{array}$ & $\mathrm{CT}$ & NA & Scattered Site & $\begin{array}{l}\text { Monthly Rental } \\
\text { Assistance (up } \\
\text { to } \\
\$ 1,314 / \text { month) }\end{array}$ & Public & $\mathrm{R}$ & CM; referrals & None & $\begin{array}{l}\text { During } \\
\text { participation }\end{array}$ & NA \\
\hline $\begin{array}{l}\text { District of Columbia } \\
\text { Child and Family } \\
\text { Services Agency }\end{array}$ & Rapid Housing & DC & NA & Scattered Site & $\begin{array}{l}\text { Monthly Rental } \\
\text { Assistance }\end{array}$ & Public & $\begin{array}{l}\mathrm{R}-30 \% \text { of } \\
\text { Income }\end{array}$ & $\mathrm{CM}$ & None & $\begin{array}{l}\text { During } \\
\text { participation }\end{array}$ & NA \\
\hline $\begin{array}{l}\text { Big Bend } \\
\text { Community-Based } \\
\text { Care }\end{array}$ & $\begin{array}{l}\text { Independence } \\
\text { Village }\end{array}$ & $\mathrm{FL}$ & $\begin{array}{l}2011 \\
\text { (Planned }\end{array}$ & Clustered & Subsidized Unit & Both & $\mathrm{R}$ & NA & NA & NA & NA \\
\hline $\begin{array}{l}\text { City of Pembroke } \\
\text { Pines }\end{array}$ & $\begin{array}{l}\text { Pembroke Pines } \\
\text { Transitional } \\
\text { Independent Living } \\
\text { Program }\end{array}$ & $\mathrm{FL}$ & 2007 & Clustered & Subsidized Unit & Public & $R$ & $\begin{array}{l}\text { On-site } \\
\text { supervision; } \\
\text { CM }\end{array}$ & YES & NA & NA \\
\hline $\begin{array}{l}\text { Florida Department } \\
\text { of Children and } \\
\text { Families }\end{array}$ & $\begin{array}{l}\text { Florida's Road to } \\
\text { Independence }\end{array}$ & $\mathrm{FL}$ & 2002 & Scattered Site & $\begin{array}{l}\text { Stipend (up to } \\
\$ 1,013 / \text { month) }\end{array}$ & Public & $\mathrm{R}$ & None & None & NA & NA \\
\hline $\begin{array}{l}\text { Florida Department } \\
\text { of Children and } \\
\text { Families }\end{array}$ & $\begin{array}{l}\text { Florida's Transitional } \\
\text { Support Services }\end{array}$ & $\mathrm{FL}$ & 2002 & Scattered Site & Stipend & Public & $\mathrm{R}$ & $\begin{array}{l}\text { Off-site } \\
\text { services }\end{array}$ & No & NA & NA \\
\hline
\end{tabular}




\begin{tabular}{|c|c|c|c|c|c|c|c|c|c|c|c|}
\hline $\begin{array}{l}\text { Lead Agency or } \\
\text { Agencies }\end{array}$ & Program Name & State & $\begin{array}{l}\text { Start } \\
\text { Date }\end{array}$ & Housing Type & $\begin{array}{l}\text { Form of } \\
\text { Housing } \\
\text { Assistance }\end{array}$ & $\begin{array}{l}\text { Funding } \\
\text { Source }\end{array}$ & $\begin{array}{l}\text { Required } \\
\text { Contribution } \\
\text { to Rent or } \\
\text { Savings }\end{array}$ & $\begin{array}{l}\text { Delivery of } \\
\text { Supportive } \\
\text { Services }\end{array}$ & $\begin{array}{l}\text { On-Site } \\
\text { Supervision }\end{array}$ & $\begin{array}{l}\text { Participant } \\
\text { Tracking }\end{array}$ & $\begin{array}{l}\text { Program } \\
\text { Evaluation }\end{array}$ \\
\hline $\begin{array}{l}\text { Henderson Mental } \\
\text { Health Center }\end{array}$ & $\begin{array}{l}\text { Wilson Garden's } \\
\text { Transitional Living }\end{array}$ & $\mathrm{FL}$ & By 2009 & Clustered & Subsidized Unit & Both & NA & $\mathrm{CM}$ & YES & NA & NA \\
\hline $\begin{array}{l}\text { Intervention } \\
\text { Services } \\
\text { Incorporated }\end{array}$ & $\begin{array}{l}\text { Village Transitional } \\
\text { Living Program }\end{array}$ & $\mathrm{FL}$ & NA & Clustered & Subsidized Unit & Both & $\mathrm{R}$ & $\begin{array}{l}\text { On-site } \\
\text { services; CM }\end{array}$ & YES & NA & NA \\
\hline Place of Hope, Inc. & Villages of Hope & $\mathrm{FL}$ & 2006 & Clustered & Subsidized Unit & Private & $\mathrm{R}$ & $\begin{array}{l}\text { On-site } \\
\text { services; CM }\end{array}$ & YES & NA & NA \\
\hline Vita Nova, Inc. & $\begin{array}{l}\text { Vita Nova of } \\
\text { Renaissance Village }\end{array}$ & $\mathrm{FL}$ & 2005 & Clustered & Subsidized Unit & Private & $\mathrm{R}$ & $\begin{array}{l}\text { On-site } \\
\text { services }\end{array}$ & NA & NA & NA \\
\hline $\begin{array}{l}\text { lowa Department of } \\
\text { Human Services \& } \\
\text { the lowa Aftercare } \\
\text { Services Network }\end{array}$ & $\begin{array}{l}\text { lowa Preparation for } \\
\text { Adult Living (PAL) }\end{array}$ & IA & 2006 & Scattered Site & $\begin{array}{l}\text { Stipend (up to } \\
\$ 547 / \text { month) }\end{array}$ & Public & $\mathrm{R}$ & $\mathrm{CM}$; referrals & None & $\begin{array}{l}\text { During } \\
\text { participation } \\
\text { and at exit. } \\
\text { Also part of } \\
\text { NYTD } \\
\text { reporting } \\
\text { requirement } \\
\text { s. }\end{array}$ & $\begin{array}{l}\text { Annual } \\
\text { outcomes } \\
\text { report and } \\
\text { sem-annual } \\
\text { consumer } \\
\text { satisfaction } \\
\text { survey by } \\
\text { lowa Youth } \\
\text { Policy } \\
\text { Institute. }\end{array}$ \\
\hline $\begin{array}{l}\text { lowa Finance } \\
\text { Authority }\end{array}$ & $\begin{array}{l}\text { lowa Aftercare Rent } \\
\text { Subsidy Program }\end{array}$ & IA & NA & Scattered Site & $\begin{array}{l}\text { Monthly Rental } \\
\text { Assistance }\end{array}$ & Public & $\begin{array}{l}\mathrm{R}-30 \% \text { of } \\
\text { Income }\end{array}$ & None & None & NA & NA \\
\hline $\begin{array}{l}\text { Illinois Department } \\
\text { of Children and } \\
\text { Family Services }\end{array}$ & $\begin{array}{l}\text { Illinois Youth } \\
\text { Housing Assistance } \\
\text { Program }\end{array}$ & IL & By 2000 & Scattered Site & $\begin{array}{l}\text { Monthly Rental } \\
\text { Assistance (up } \\
\text { to } \\
\$ 250 / \text { month) }\end{array}$ & Public & R - Grad & $\begin{array}{l}\text { Housing } \\
\text { advocacy } \\
\text { only }\end{array}$ & None & NA & NA \\
\hline $\begin{array}{l}\text { Interfaith Housing } \\
\text { Development } \\
\text { Corporation of } \\
\text { Chicago } \\
\text { Coppin House Social } \\
\text { Services } \\
\text { Sankofa House }\end{array}$ & $\begin{array}{l}\text { Interfaith Housing } \\
\text { Development } \\
\text { Corporation of } \\
\text { Chicago Permanent } \\
\text { Supportive Housing } \\
\text { Program }\end{array}$ & IL & 2008 & Clustered & Subsidized Unit & Both & $\begin{array}{l}\mathrm{R}-30 \% \text { of } \\
\text { Income (only } \\
\text { if employed) }\end{array}$ & $\begin{array}{l}\text { On-site } \\
\text { services; CM; } \\
\text { referrals }\end{array}$ & NA & NA & NA \\
\hline Rediscovery Inc. & $\begin{array}{l}\text { Rediscovery Inc. } \\
\text { Group Home }\end{array}$ & MA & NA & Clustered & & Private & NA & $\begin{array}{l}\text { On-site } \\
\text { services; CM }\end{array}$ & YES & $\begin{array}{l}\text { During } \\
\text { participation }\end{array}$ & NA \\
\hline Rediscovery Inc. & $\begin{array}{l}\text { Rediscovery Inc. } \\
\text { Independent Living } \\
\text { Program }\end{array}$ & MA & NA & Scattered Site & NA & Private & NA & $\begin{array}{l}\mathrm{CM} \text {; off-site } \\
\text { services }\end{array}$ & None & $\begin{array}{l}\text { During } \\
\text { participation }\end{array}$ & NA \\
\hline $\begin{array}{l}\text { AIRS (AIDS Interfaith } \\
\text { Residential Services) }\end{array}$ & Restoration Gardens & MD & 2010 & Clustered & Subsidized Unit & Both & $\begin{array}{l}\mathrm{R}-30 \% \text { of } \\
\text { Income }\end{array}$ & $\begin{array}{l}\text { On-site } \\
\text { services }\end{array}$ & YES & NA & NA \\
\hline $\begin{array}{l}\text { Life's Missing Link, } \\
\text { Inc. } \\
\text { RS Eden, Inc. }\end{array}$ & $\begin{array}{l}\text { Lindquist } \\
\text { Apartments }\end{array}$ & $\mathrm{MN}$ & 2005 & Clustered & Subsidized Unit & Both & NA & $\begin{array}{l}\text { On-site } \\
\text { services; CM; } \\
\text { referrals }\end{array}$ & YES & NA & NA \\
\hline
\end{tabular}




\begin{tabular}{|c|c|c|c|c|c|c|c|c|c|c|c|}
\hline $\begin{array}{l}\text { Lead Agency or } \\
\text { Agencies }\end{array}$ & Program Name & State & $\begin{array}{l}\text { Start } \\
\text { Date }\end{array}$ & Housing Type & $\begin{array}{l}\text { Form of } \\
\text { Housing } \\
\text { Assistance }\end{array}$ & $\begin{array}{l}\text { Funding } \\
\text { Source }\end{array}$ & $\begin{array}{l}\text { Required } \\
\text { Contribution } \\
\text { to Rent or } \\
\text { Savings }\end{array}$ & $\begin{array}{l}\text { Delivery of } \\
\text { Supportive } \\
\text { Services }\end{array}$ & $\begin{array}{l}\text { On-Site } \\
\text { Supervision }\end{array}$ & $\begin{array}{l}\text { Participant } \\
\text { Tracking }\end{array}$ & $\begin{array}{l}\text { Program } \\
\text { Evaluation }\end{array}$ \\
\hline $\begin{array}{l}\text { RS Eden } \\
\text { Growing Homes }\end{array}$ & Seventh Landing & $\mathrm{MN}$ & 2003 & Clustered & Subsidized Unit & Both & $\begin{array}{l}\mathrm{R}-30 \% \text { of } \\
\text { Income }\end{array}$ & $\begin{array}{l}\text { On-site } \\
\text { services; CM; } \\
\text { referrals }\end{array}$ & YES & NA & NA \\
\hline The Salvation Army & $\begin{array}{l}\text { Booth Brown Foyer } \\
\text { Housing Permanent } \\
\text { Supportive Housing }\end{array}$ & $\mathrm{MN}$ & 2003 & Clustered & Subsidized Unit & Private & $\begin{array}{l}\mathrm{R}-30 \% \text { of } \\
\text { Income } \\
\mathrm{S}-10 \% \\
\text { Income }\end{array}$ & $\begin{array}{l}\text { On-site } \\
\text { services; CM; } \\
\text { referrals }\end{array}$ & YES & $\begin{array}{l}\text { During } \\
\text { participation } \\
\text { and at exit }\end{array}$ & NA \\
\hline The Salvation Army & $\begin{array}{l}\text { Booth Brown Foyer } \\
\text { Housing Transitional } \\
\text { Living Program }\end{array}$ & MN & 2003 & Clustered & Subsidized Unit & Private & $\begin{array}{l}\mathrm{R}-30 \% \text { of } \\
\text { Income } \\
\mathrm{S}-10 \% \text { of } \\
\text { Income }\end{array}$ & $\begin{array}{l}\text { On-site } \\
\text { services; CM; } \\
\text { referrals }\end{array}$ & YES & $\begin{array}{l}\text { During } \\
\text { participation } \\
\text { and at exit }\end{array}$ & NA \\
\hline $\begin{array}{l}\text { North Carolina } \\
\text { Department of } \\
\text { Health and Human } \\
\text { Services, Division of } \\
\text { Social Services }\end{array}$ & North Carolina LINKS & NC & NA & Scattered Site & $\begin{array}{l}\text { Stipend (up to } \\
\$ 1,999 \\
\text { lifetime) }\end{array}$ & Public & $\mathrm{R}$ & CM; referrals & None & $\begin{array}{l}\text { Part of NYTD } \\
\text { reporting } \\
\text { requirement } \\
\text { s. }\end{array}$ & NA \\
\hline $\begin{array}{l}\text { Nashua Children's } \\
\text { Home }\end{array}$ & $\begin{array}{l}\text { Nashua Children's } \\
\text { Home Transitional } \\
\text { Living Program }\end{array}$ & $\mathrm{NH}$ & 2004 & Clustered & Subsidized Unit & Both & $\mathrm{R}$ & $\begin{array}{l}\text { On-site } \\
\text { services }\end{array}$ & NA & NA & NA \\
\hline $\begin{array}{l}\text { New Hampshire } \\
\text { Child and Family } \\
\text { Services }\end{array}$ & $\begin{array}{l}\text { New Hampshire } \\
\text { Transitional Living } \\
\text { Program }\end{array}$ & $\mathrm{NH}$ & NA & Clustered & Subsidized Unit & Public & $\begin{array}{l}R \\
S\end{array}$ & $\mathrm{CM}$ & NA & NA & NA \\
\hline $\begin{array}{l}\text { New Jersey Housing } \\
\text { and Mortgage } \\
\text { Finance Agency }\end{array}$ & $\begin{array}{l}\text { New Jersey Youth } \\
\text { Supportive Housing } \\
\text { Initiative }\end{array}$ & NJ & 2005 & Clustered & Subsidized Unit & Public & $\mathrm{R}$ & $\begin{array}{l}\text { On-site } \\
\text { services; CM; } \\
\text { referrals }\end{array}$ & NA & NA & NA \\
\hline $\begin{array}{l}\text { New Mexico } \\
\text { Children, Youth and } \\
\text { Families } \\
\text { Department } \\
\text { New Mexico } \\
\text { Behavioral Health } \\
\text { Collaborative } \\
\text { Supportive Housing } \\
\text { Coalition of New } \\
\text { Mexico } \\
\text { ValueOptions New } \\
\text { Mexico }\end{array}$ & $\begin{array}{l}\text { Transitions } \\
\text { Permanent } \\
\text { Supportive Housing }\end{array}$ & NM & 2007 & Scattered Site & $\begin{array}{l}\text { Monthly Rental } \\
\text { Assistance }\end{array}$ & Public & $\begin{array}{l}\mathrm{R}-30 \% \text { of } \\
\text { Income }\end{array}$ & $\begin{array}{l}\text { CM; referrals; } \\
\text { Transition } \\
\text { Services } \\
\text { program }\end{array}$ & None & NA & $\begin{array}{l}\text { Unclear if } \\
\text { planned } \\
\text { evaluation } \\
\text { of pilot } \\
\text { program } \\
\text { was } \\
\text { conducted. }\end{array}$ \\
\hline $\begin{array}{l}\text { City of Las Vegas } \\
\text { Housing Authority } \\
\text { Clark County } \\
\text { Department of } \\
\text { Family Services }\end{array}$ & $\begin{array}{l}\text { Las Vegas HCV } \\
\text { Preference Program }\end{array}$ & NV & 2008 & Scattered Site & $\begin{array}{l}\text { Monthly Rental } \\
\text { Assistance }\end{array}$ & Public & $\begin{array}{l}\mathrm{R}-30 \% \text { of } \\
\text { Income }\end{array}$ & $\mathrm{CM}$ & None & $\begin{array}{l}\text { During } \\
\text { participation }\end{array}$ & NA \\
\hline $\begin{array}{l}\text { Clark County Social } \\
\text { Service Department }\end{array}$ & Step-Up Program & NV & NA & Scattered Site & $\begin{array}{l}\text { Stipend (up to } \\
\$ 800 \text { lifetime) }\end{array}$ & Public & $\mathrm{R}$ & $\begin{array}{l}\text { Off-site life } \\
\text { skills training }\end{array}$ & None & NA & NA \\
\hline
\end{tabular}




\begin{tabular}{|c|c|c|c|c|c|c|c|c|c|c|c|}
\hline $\begin{array}{l}\text { Lead Agency or } \\
\text { Agencies }\end{array}$ & Program Name & State & $\begin{array}{l}\text { Start } \\
\text { Date }\end{array}$ & Housing Type & $\begin{array}{l}\text { Form of } \\
\text { Housing } \\
\text { Assistance }\end{array}$ & $\begin{array}{l}\text { Funding } \\
\text { Source }\end{array}$ & $\begin{array}{l}\text { Required } \\
\text { Contribution } \\
\text { to Rent or } \\
\text { Savings }\end{array}$ & $\begin{array}{l}\text { Delivery of } \\
\text { Supportive } \\
\text { Services }\end{array}$ & $\begin{array}{l}\text { On-Site } \\
\text { Supervision }\end{array}$ & $\begin{array}{l}\text { Participant } \\
\text { Tracking }\end{array}$ & $\begin{array}{l}\text { Program } \\
\text { Evaluation }\end{array}$ \\
\hline $\begin{array}{l}\text { Edwin Gould } \\
\text { Academy }\end{array}$ & $\begin{array}{l}\text { Edwin Gould } \\
\text { Residence }\end{array}$ & NY & 2006 & Clustered & Subsidized Unit & Both & $\begin{array}{l}R-30 \%-40 \% \\
\text { of Income }\end{array}$ & $\begin{array}{l}\text { On-site } \\
\text { services; CM; } \\
\text { Exodus } \\
\text { Partnership }\end{array}$ & YES & $\begin{array}{l}\text { During } \\
\text { participation }\end{array}$ & NA \\
\hline $\begin{array}{l}\text { Good Shepherd } \\
\text { Services } \\
\text { Common Ground }\end{array}$ & Chelsea Foyer & NY & 2004 & Clustered & Subsidized Unit & Both & $\begin{array}{l}\text { S- } 30 \% \text { of } \\
\text { Income }\end{array}$ & $\begin{array}{l}\text { On-site } \\
\text { services; CM }\end{array}$ & YES & $\begin{array}{l}\text { During } \\
\text { participation } \\
\text { and after } \\
\text { exit }\end{array}$ & $\begin{array}{l}\text { Internal } \\
\text { evaluation }\end{array}$ \\
\hline $\begin{array}{l}\text { Lantern } \\
\text { Organization } \\
\text { Community Lantern } \\
\text { Corporation }\end{array}$ & Schafer Hall & NY & 2001 & Clustered & Subsidized Unit & Public & $\begin{array}{l}\mathrm{R}-30 \% \text { of } \\
\text { Income }\end{array}$ & $\begin{array}{l}\text { On-site } \\
\text { services; CM; } \\
\text { referrals }\end{array}$ & YES & $\begin{array}{l}\text { During } \\
\text { participation }\end{array}$ & NA \\
\hline $\begin{array}{l}\text { New York City } \\
\text { Department of } \\
\text { Health and Mental } \\
\text { Hygiene }\end{array}$ & $\begin{array}{l}\text { New York/New York } \\
\text { III }\end{array}$ & NY & 2005 & $\begin{array}{l}\text { Clustered } \\
\text { Scattered Site }\end{array}$ & $\begin{array}{l}\text { Subsidized unit } \\
\text { Monthly Rental } \\
\text { Assistance }\end{array}$ & Public & $\begin{array}{l}\mathrm{R}-30 \% \text { of } \\
\text { Income }\end{array}$ & CM; referrals & YES & $\begin{array}{l}\text { During } \\
\text { participation } \\
\text { and after } \\
\text { exit }\end{array}$ & $\begin{array}{l}\text { Internal } \\
\text { evaluation } \\
\text { by city and } \\
\text { state } \\
\text { agencies }\end{array}$ \\
\hline $\begin{array}{l}\text { New York State } \\
\text { Office of Children } \\
\text { and Family Services }\end{array}$ & $\begin{array}{l}\text { New York City } \\
\text { Section } 8 \text { Priority } \\
\text { Code }\end{array}$ & NY & NA & Scattered Site & $\begin{array}{l}\text { Monthly Rental } \\
\text { Assistance }\end{array}$ & Public & $\begin{array}{l}\mathrm{R}-30 \% \text { of } \\
\text { Income }\end{array}$ & None & None & NA & NA \\
\hline $\begin{array}{l}\text { Lighthouse Youth } \\
\text { Services }\end{array}$ & $\begin{array}{l}\text { Lighthouse } \\
\text { Emancipated Youth } \\
\text { Program }\end{array}$ & $\mathrm{OH}$ & NA & Clustered & Subsidized Unit & Public & NA & NA & YES & $\begin{array}{l}\text { During } \\
\text { participation } \\
\text { and at exit }{ }^{c}\end{array}$ & NA \\
\hline $\begin{array}{l}\text { Oregon Department } \\
\text { of Human Services }\end{array}$ & $\begin{array}{l}\text { Oregon's Chafee } \\
\text { Housing Program }\end{array}$ & OR & NA & Scattered Site & $\begin{array}{l}\text { Stipend (up to } \\
\$ 600 / \text { month or } \\
\$ 6,000 \\
\text { lifetime) }\end{array}$ & Public & $\mathrm{R}$ & NA & None & NA & NA \\
\hline $\begin{array}{l}\text { Rhode Island } \\
\text { Council on } \\
\text { Residential } \\
\text { Programs for } \\
\text { Children and Youth }\end{array}$ & $\begin{array}{l}\text { YESS (Young Adults } \\
\text { Establishing Self } \\
\text { Sufficiency) }\end{array}$ & RI & 2004 & Scattered Site & $\begin{array}{l}\text { Monthly Rental } \\
\text { Assistance }\end{array}$ & Public & R - Grad & $\begin{array}{l}\mathrm{CM} \text {; referrals; } \\
\text { life skills } \\
\text { training }\end{array}$ & None & $\begin{array}{l}\text { During } \\
\text { participation }\end{array}$ & NA \\
\hline $\begin{array}{l}\text { Foster Youth Life } \\
\text { Investment Partners }\end{array}$ & $\begin{array}{l}\text { Foster Youth Life } \\
\text { Investment Partners }\end{array}$ & TX & 2004 & Scattered Site & $\begin{array}{l}\text { Monthly Rental } \\
\text { Assistance }\end{array}$ & Both & $\mathrm{R}$ & None & None & NA & NA \\
\hline $\begin{array}{l}\text { Texas Department } \\
\text { of Family and } \\
\text { Protective Services }\end{array}$ & $\begin{array}{l}\text { Texas AFTERCARE } \\
\text { ROOM AND BOARD } \\
\text { ASSISTANCE Program }\end{array}$ & TX & 2000 & Scattered Site & $\begin{array}{l}\text { Stipend (up to } \\
\$ 500 / \text { month or } \\
\$ 3,000 \\
\text { lifetime) }\end{array}$ & Public & R - Grad & CM; referrals & None & $\begin{array}{l}\text { During } \\
\text { participation }\end{array}$ & NA \\
\hline $\begin{array}{l}\text { Texas Department } \\
\text { of Family and } \\
\text { Protective Services }\end{array}$ & $\begin{array}{l}\text { Texas } \\
\text { TRANSITIONAL } \\
\text { LIVING ALLOWANCE } \\
\text { Program }\end{array}$ & TX & 2000 & Scattered Site & $\begin{array}{l}\text { Stipend (up to } \\
\$ 1,000 \\
\text { lifetime) }\end{array}$ & Public & $\mathrm{R}$ & CM; referrals & None & $\begin{array}{l}\text { During } \\
\text { participation }\end{array}$ & NA \\
\hline
\end{tabular}




\begin{tabular}{|c|c|c|c|c|c|c|c|c|c|c|c|}
\hline $\begin{array}{l}\text { Lead Agency or } \\
\text { Agencies }\end{array}$ & Program Name & State & $\begin{array}{l}\text { Start } \\
\text { Date }\end{array}$ & Housing Type & $\begin{array}{l}\text { Form of } \\
\text { Housing } \\
\text { Assistance }\end{array}$ & $\begin{array}{l}\text { Funding } \\
\text { Source }\end{array}$ & $\begin{array}{l}\text { Required } \\
\text { Contribution } \\
\text { to Rent or } \\
\text { Savings }\end{array}$ & $\begin{array}{l}\text { Delivery of } \\
\text { Supportive } \\
\text { Services }\end{array}$ & $\begin{array}{c}\text { On-Site } \\
\text { Supervision }\end{array}$ & $\begin{array}{l}\text { Participant } \\
\text { Tracking }\end{array}$ & $\begin{array}{l}\text { Program } \\
\text { Evaluation }\end{array}$ \\
\hline $\begin{array}{l}\text { Washington } \\
\text { Department of } \\
\text { Commerce } \\
\text { Washington } \\
\text { Department of } \\
\text { Social and Health } \\
\text { Services }\end{array}$ & $\begin{array}{l}\text { Washington State } \\
\text { Independent Youth } \\
\text { Housing Program }\end{array}$ & WA & 2007 & Scattered Site & $\begin{array}{l}\text { Monthly Rental } \\
\text { Assistance }\end{array}$ & Public & $\begin{array}{l}R \\
S\end{array}$ & CM; referrals & None & $\begin{array}{l}\text { During } \\
\text { participation }\end{array}$ & NA \\
\hline $\begin{array}{l}\text { YMCA of Greater } \\
\text { Seattle }\end{array}$ & $\begin{array}{l}\text { YMCA of Greater } \\
\text { Seattle }\end{array}$ & WA & NA & $\begin{array}{l}\text { Clustered } \\
\text { Scattered Site }\end{array}$ & $\begin{array}{l}\text { Subsidized Unit } \\
\text { (C) } \\
\text { Monthly Rental } \\
\text { Assistance (S) }\end{array}$ & Public & $\begin{array}{l}\mathrm{R}-30 \% \text { of } \\
\text { Income }\end{array}$ & $\begin{array}{l}\text { On-site } \\
\text { services }\end{array}$ & YES & NA & NA \\
\hline $\begin{array}{l}\text { St. Aemilian- } \\
\text { Lakeside }\end{array}$ & $\begin{array}{l}\text { Youth Moving On } \\
\text { (Milwaukee) }\end{array}$ & WI & 2009 & Scattered Site & NA & Both & R - Grad & CM; services & None & NA & NA \\
\hline
\end{tabular}

Notes:

\section{Delivery of Supportive Services:}

On-site services: supportive services are provided where the youth live

Off-site services: supportive services provided by another agency/organization that partners with the program

$\mathrm{CM}$ : Case management

Referrals: youth are referred out to services available in the community

None: Not provided

NA: Information was not found

\section{Type of Housing Assistance:}

Subsidized: unit located in a building owned/managed by the program

Monthly rental assistance: help paying rent, such as a voucher

Stipend: time-limited grant or allowance for rent, room and board, or other living expenses

\section{Housing Type:}

Clustered (single, multi-unit building dedicated to youth and young adults)

Scattered Site (housing dispersed throughout the community and usually rented from a private landlord) (Assumed if program provides only monthly assistance)

Host Homes (youth lives with foster family or other caring adult who receives a monthly subsidy).

\section{Required Contribution to Rent or Savings:}

$\mathrm{R}$ : youth contribution to rent (assumed if program provides monthly rental assistance)

R- Grad: graduated rent payments (i.e., youth contribution increases over time until it reaches $100 \%$ of rent

S: youth contribution to savings

Required contribution to rent may be different for different housing options within a single program.

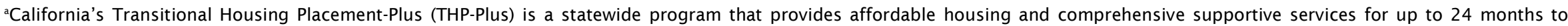

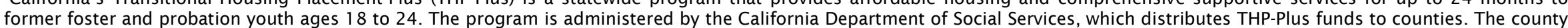

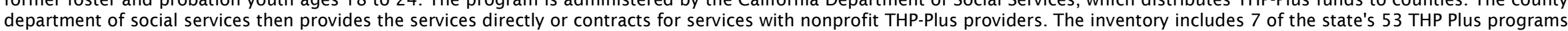
(as of July 2011).

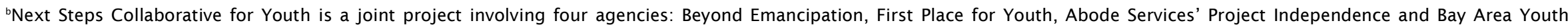
Centers (BAYC). The first three agencies operate programs that are included in the inventory. The fourth provides mental health services.

c "Chelsea Foyer at 5 years: Lessons in Developing Stable Housing and Self-Sufficiency for Homeless Youth and Youth Exiting Foster Care", 2009. 

